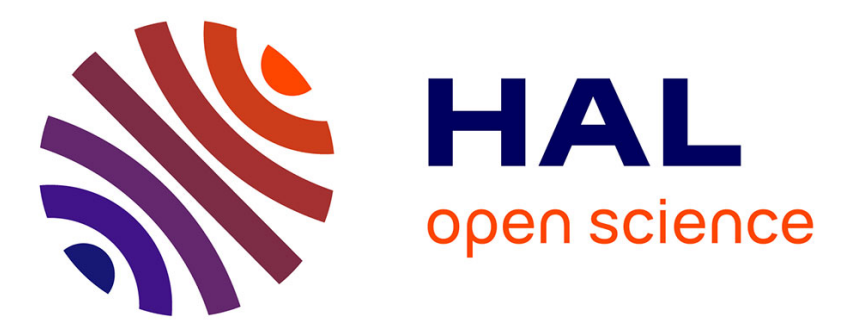

\title{
Structural and electrochemical studies of a new tavorite composition: LiVPO4OH
}

Edouard Boivin, Jean-Noël Chotard, Michel Ménétrier, Lydie Bourgeois, Tahya Bamine, Dany Carlier, François Fauth, Emmanuelle Suard, Christian Masquelier, Laurence Croguennec

\section{To cite this version:}

Edouard Boivin, Jean-Noël Chotard, Michel Ménétrier, Lydie Bourgeois, Tahya Bamine, et al.. Structural and electrochemical studies of a new tavorite composition: LiVPO4OH. Journal of Materials Chemistry A, 2016, 4 (28), pp.11030-11045. 10.1039/c6ta03339c . hal-01348196

\author{
HAL Id: hal-01348196 \\ https://hal.science/hal-01348196
}

Submitted on 1 Feb 2021

HAL is a multi-disciplinary open access archive for the deposit and dissemination of scientific research documents, whether they are published or not. The documents may come from teaching and research institutions in France or abroad, or from public or private research centers.
L'archive ouverte pluridisciplinaire HAL, est destinée au dépôt et à la diffusion de documents scientifiques de niveau recherche, publiés ou non, émanant des établissements d'enseignement et de recherche français ou étrangers, des laboratoires publics ou privés. 


\section{Structural and Electrochemical Studies of a New Tavorite Composition: $\mathrm{LiVPO}_{4} \mathrm{OH}$}

\footnotetext{
Edouard Boivin $^{\text {a,b, g, Jean-Noël Chotard }}{ }^{\text {b, g, h }}$, Michel Ménétrier ${ }^{a}$, , Lydie Bourgeois ${ }^{c, d}$, Tahya Bamine ${ }^{a, g}$, Dany Carlier ${ }^{a, g}$, François Fauth ${ }^{e}$, Emmanuelle Suard ${ }^{f}$, Christian Masquelier $^{\mathrm{b}, \mathrm{g}, \mathrm{h}}$ and Laurence Croguennec ${ }^{\mathrm{a}, \mathrm{g}, \mathrm{h}, *}$

${ }^{a}$ CNRS, Univ. Bordeaux, Bordeaux INP, ICMCB UPR 9048, F-33600 Pessac, France.

${ }^{b}$ Laboratoire de Réactivité et de Chimie des Solides, CNRS-UMR\#7314, Université de Picardie Jules Verne, F-80039 Amiens Cedex 1, France.

'Université de Bordeaux, ISM, Groupe de Spectroscopie Moléculaire, F-33405 Talence, France.

${ }^{d}$ Bordeaux INP, ISM, CNRS, UMR 5255, F-33405, Talence, France.

${ }^{e}$ CELLS - ALBA synchrotron, E-08290 Cerdanyola del Vallès, Barcelona, Spain.

${ }^{f}$ Institut Laue-Langevin, 71 Avenue des Martyrs, F-38000 Grenoble, France.

${ }^{g}$ RS2E, Réseau Français sur le Stockage Electrochimique de l'Energie, FR CNRS 3459, F-80039 Amiens Cedex 1, France.

${ }^{h}$ ALISTORE-ERI European Research Institute, FR CNRS 3104, F-80039 Amiens Cedex 1, France.
}

"Corresponding author (L. Croguennec): Laurence.Croguennec@icmcb.cnrs.fr 


\begin{abstract}
Polyanionic materials attract a strong interest in the field of Li-ion battery research thanks to the wide range of compositions, structures and electrochemical properties they offer. Tavorite-type compositions offer a very rich crystal chemistry, among which LiVPO ${ }_{4} \mathrm{~F}$ has the highest theoretical energy density (i.e. $655 \mathrm{Wh} / \mathrm{kg}$ ). A new Tavorite-type $\mathrm{LiVPO}_{4} \mathrm{OH}$ composition was synthetized by hydrothermal route from three different vanadiumcontaining precursors. The crystal structure of this new phase was fully determined thanks to synchrotron $\mathrm{X}$-ray and neutron diffraction. ${ }^{1} \mathrm{H},{ }^{7} \mathrm{Li}$, and ${ }^{31} \mathrm{P}$ magic angle spinning nuclear magnetic resonance spectroscopy as well as diffuse reflectance infra-red spectroscopy were performed in order to support further the nature of the phases formed. Galvanostatic intermittent titration technique experiments in Lithium batteries and ex-situ X-ray diffraction analyses revealed that during oxidation, the concomitant extraction of $\mathrm{Li}^{+}$and $\mathrm{H}^{+}$occurs at the same equilibrium potential $\left(3.95 \mathrm{~V} \mathrm{vs} \mathrm{Li}^{+} / \mathrm{Li}\right)$ and leads to the formation of the Tavorite phase $\mathrm{VPO}_{4} \mathrm{O}$ at the end of the charge. $\mathrm{LiVPO}_{4} \mathrm{OH}$ is also electrochemically active in the low voltage region, upon $\mathrm{Li}^{+}$insertion. The reversible insertion/extraction of lithium at $1.35 \mathrm{~V}$ vs $\mathrm{Li}^{+} / \mathrm{Li}$ leads to the formation of $\mathrm{Li}_{2} \mathrm{VPO}_{4} \mathrm{OH}$ at the end of discharge.
\end{abstract}




\section{Introduction}

The development of new positive electrode materials for high energy density Lithium-ion batteries is one of the main issues for research in the field, both at the academic and industrial levels. Materials such as $\mathrm{LiM}^{1}{ }_{1-x-y} \mathrm{M}^{2}{ }_{x} \mathrm{M}^{3}{ }_{\mathrm{y}} \mathrm{O}_{2}$ with $\mathrm{M}=\mathrm{Co}, \mathrm{Ni}, \mathrm{Mn}, \mathrm{Al} \ldots\left(\mathrm{LiCoO}_{2}{ }^{1}\right.$, $\mathrm{LiNi}_{0.80} \mathrm{CO}_{0.15} \mathrm{Al}_{0.05} \mathrm{O}_{2}{ }^{2}$ and $\mathrm{LiNi}_{1 / 3} \mathrm{Mn}_{1 / 3} \mathrm{Co}_{1 / 3} \mathrm{O}_{2}{ }^{3} \ldots$ ) layered oxides exhibit good performances and are already industrially developed. $\mathrm{LiCoO}_{2}$ is for instance the most encountered in Lithium-ion batteries used in mobile devices since 1991. Nevertheless, its cost and limited thermal stability in the charged state of the battery ${ }^{4}$ promoted the development of nickelrich layered oxides such as $\mathrm{LiNi}_{0.80} \mathrm{Co}_{0.15} \mathrm{Al}_{0.05} \mathrm{O}_{2}$ for transport applications. Polyanionic compounds became the subject of intense research since the discovery by J.B. Goodenough and coworkers ${ }^{5}$ of reversible Lithium extraction/insertion from/in the olivine-type $\mathrm{LiFePO}_{4}$. Indeed, this sustainable material demonstrated excellent chemical and thermal stability, as well as excellent cyclability even at high rates. Its main drawback is in fact its low working potential (3.45 V vs. $\mathrm{Li}^{+} / \mathrm{Li}$ ) and thus an energy density still limited for transport applications. Polyanionic compounds are built of $\mathrm{MO}_{6}$ octahedra $\left(\mathrm{M}=\right.$ transition metal) and $\mathrm{XO}_{\mathrm{n}}$ polyhedra $(\mathrm{X}=\mathrm{P}, \mathrm{S}, \mathrm{Si}, \mathrm{B} \ldots)^{6-9}$, with a variety of bi- or three-dimensional frameworks with open interstitial spaces available for easy alkali ions diffusion. Despite a penalty in the gravimetric energy density of these materials, the higher electronegativity of the polyanionic groups versus that of oxygen tends to increase, by inductive effect, the difference of potential with lithium reference of a given redox couple versus that observed in oxides. Furthermore, it is possible to tune further this potential by changing the nature of the polyanionic group as was nicely demonstrated in Nasicon-type structures $A_{3} M_{2}\left(X_{4}\right)_{3}(A=L i, N a ; M=F e, T i, V \ldots, X$ $=P, W, M o, S \ldots)$ moving from phosphates to tungstates, molybdates and sulfates ${ }^{10,11}$.

Among these polyanionic structures, the Tavorite-like $\mathrm{AMXO}_{4} \mathrm{Y}(\mathrm{A}=\mathrm{H}, \mathrm{Li}, \mathrm{Na} ; \mathrm{M}=\mathrm{V}$, $\mathrm{Fe}, \mathrm{Mn}, \mathrm{Ti} \ldots ; \mathrm{X}=\mathrm{P}, \mathrm{S}$ and $\mathrm{Y}=\mathrm{O}, \mathrm{F}, \mathrm{OH}$ ) offers a large panel of compositions ${ }^{6,12-19}$. In this structure, the $\mathrm{MO}_{4} \mathrm{Y}_{2}$ octahedra are linked by the bridging anion $\mathrm{Y}$ to form infinite $\left[\mathrm{Y}-\mathrm{MO}_{4^{-}}\right.$ $\mathrm{Y}]_{\infty}$ chains. These chains are connected by $\mathrm{XO}_{4}$ tetrahedra to form a three dimensional network and channels for ionic diffusion ${ }^{20}$. Playing with the nature of the polyanionic group, the bridging anion and/or the transition metal, it is possible to tailor the potential from $1.5 \mathrm{~V}$ vs. $\mathrm{Li}^{+} / \mathrm{Li}$ for the titanium oxyphosphate ${ }^{21}$ to $4.24 \mathrm{~V}$ vs. $\mathrm{Li}^{+} / \mathrm{Li}$ for the vanadium 
fluorophosphate ${ }^{22}$. For instance, moving from $\mathrm{LiFePO}_{4} \mathrm{OH}^{13}$, to $\mathrm{LiFePO}_{4} \mathrm{~F}$ and then to $\mathrm{LiFeSO}_{4} \mathrm{~F}^{16}$, the operating voltage vs. $\mathrm{Li}$ for the $\mathrm{Fe}^{3+} / \mathrm{Fe}^{2+}$ redox couple increases from $2.9 \mathrm{~V}$, to $3.1 \mathrm{~V}$ and then to $3.6 \mathrm{~V}$ vs. $\mathrm{Li}^{+} / \mathrm{Li}$. All phosphate-containing Tavorite-like compositions showing an electrochemical activity in Lithium-ion batteries are listed in table 1.

Vanadium-containing Tavorite compositions are very attractive because of their high operating potential vs. Li and thus provide a theoretical energy density competitive with that of the already commercialized $\mathrm{LiFePO}_{4}$. Indeed, the most efficient Tavorite compound, $\mathrm{LiVPO}_{4} \mathrm{~F}$, is characterized by a theoretical energy density of $655 \mathrm{Wh} / \mathrm{kg}$ (against $586 \mathrm{Wh} / \mathrm{kg}$ for $\mathrm{LiFePO}_{4}$ ). $\mathrm{LiVPO}_{4} \mathrm{~F}$ was synthetized for the first time ten years ago ${ }^{22}$, and exhibits very good electrochemical performances even at high rates ${ }^{23,24,25}$ as well as good chemical stability in air, in moisture and in temperature in the charged state of the battery ${ }^{26-28}$. The lithium extraction process from $\mathrm{LiV}^{\text {III }} \mathrm{PO}_{4} \mathrm{~F}$ occurs following two successive biphasic reactions involving the $\mathrm{V}^{4+} / \mathrm{V}^{3+}$ redox couple, the first one between $\mathrm{LiVPO}_{4} \mathrm{~F}$ and $\mathrm{Li}_{2 / 3} \mathrm{VPO}_{4} \mathrm{~F}$ at $4.24 \mathrm{~V}$ vs. $\mathrm{Li}^{+} / \mathrm{Li}$, and the second one between $\mathrm{Li}_{2 / 3} \mathrm{VPO}_{4} \mathrm{~F}$ and $\mathrm{V}^{\mathrm{IV}} \mathrm{PO}_{4} \mathrm{~F}$ at $4.28 \mathrm{~V}$ vs. $\mathrm{Li}^{+} / \mathrm{Li}$. At lower voltage $\left(3.0-1.5 \mathrm{~V}\right.$ vs. $\left.\mathrm{Li}^{+} / \mathrm{Li}\right)$ it is possible to operate on the $\mathrm{V}^{3+} / \mathrm{V}^{2+}$ redox couple through reversible lithium insertion/extraction in/from $\mathrm{LiVPO}_{4} \mathrm{~F}$ at $1.8 \mathrm{~V} \mathrm{vs.} \mathrm{Li}^{+} / \mathrm{Li}$ and according to a two phase reaction mechanism leading to the formation of $\mathrm{Li}_{2} \mathrm{~V}^{\prime \prime} \mathrm{PO}_{4} \mathrm{~F}^{29}$. The possible exchange of two electrons per vanadium was thus demonstrated in $\mathrm{LiVPO}_{4} \mathrm{~F}$ even though only one can be actually used in a small enough potential window and thus in a real system. This compound is generally synthesized using a long two step ceramic synthesis route and most efforts are currently focused on the development of an eco-friendly, easy and scalable synthesis process maintaining optimized electrochemical properties ${ }^{30-34}$. $\mathrm{LiV}^{\mathrm{IV}} \mathrm{PO}_{4} \mathrm{O}$ can crystallize according to several forms $\left(\alpha_{1}, \alpha_{2}, \beta^{35}\right)$, the Tavorite-like polymorph being the most investigated. Lithium extraction occurs at $3.95 \mathrm{~V}$ vs. $\mathrm{Li}^{+} / \mathrm{Li}$ with the formation of $\varepsilon-$ $\mathrm{V}^{\mathrm{V}} \mathrm{OPO}_{4}$ through a biphasic reaction. Note that it is also possible to form $\varepsilon-\mathrm{VOPO}_{4}$ from another Tavorite-like compound, $\mathrm{VPO}_{4} \cdot \mathrm{H}_{2} \mathrm{O}$ (also called $\mathrm{HVPO}_{4} \mathrm{OH}$ or $\mathrm{H}_{2} \mathrm{VPO}_{4} \mathrm{O}$ ), by electrochemical extraction of the two $\mathrm{H}^{+}$cations ${ }^{18}$ or by thermal decomposition. In the low voltage region (3.0 - $1.5 \mathrm{~V}$ vs. $\mathrm{Li}^{+} / \mathrm{Li}$ involving the $\mathrm{V}^{4+} / \mathrm{V}^{3+}$ redox couple), $\mathrm{Li}^{+}$insertion into $\mathrm{LiVPO}_{4} \mathrm{O}$ occurs through three reversible biphasic reactions leading to the formation of $\mathrm{Li}_{1.5} \mathrm{VPO}_{4} \mathrm{O}, \mathrm{Li}_{1.75} \mathrm{VPO}_{4} \mathrm{O}$ and $\mathrm{Li}_{2} \mathrm{~V}^{\prime \prime \prime} \mathrm{PO}_{4} \mathrm{O}$ at potentials of $2.46,2.20$ and $2.02 \mathrm{~V} \mathrm{vs}$. $\mathrm{Li}^{+} / \mathrm{Li}^{36}$. 
Up to now the vanadium hydroxy-phosphate with Tavorite-like structure had never been reported except as a composition mentioned in a patent and in a $\mathrm{PhD}$ thesis manuscript ${ }^{37,38}$, and despite the existence on one side of vanadium-containing Tavorite-like phases $\left(\mathrm{LiVPO}_{4} \mathrm{~F}, \mathrm{LiVPO}_{4} \mathrm{O}\right.$ and $\mathrm{HVPO}_{4} \mathrm{OH}^{15,18}$ ) and on the other side of a series of Tavoritelike hydroxy-phosphates ( $\mathrm{LiAlPO}{ }_{4} \mathrm{OH}, \mathrm{LiFePO}_{4} \mathrm{OH}$ and $\mathrm{LiMnPO}_{4} \mathrm{OH}^{39,12,19}$ ). We report here, for the first time, on the synthesis of $\mathrm{LiVPO}_{4} \mathrm{OH}$, on its in-depth structural characterization and first insights in its electrochemical behavior. By analogy with $\mathrm{VPO}_{4} \cdot \mathrm{H}_{2} \mathrm{O}$, we are entitled to question how $\mathrm{LiVPO}_{4} \mathrm{OH}$ will behave electrochemically: is the hydroxyl group stable in this structure during cycling?

\section{Experimental part}

Syntheses were performed by hydrothermal route using Parr $23 \mathrm{~mL}$ Teflon reactors. Depending on the chemical reaction considered, different precursors were used: vanadium (III) chlorine $\left(\mathrm{VCl}_{3}\right.$, Sigma-Aldrich, 97\%), vanadium (V) oxide $\left(\mathrm{V}_{2} \mathrm{O}_{5}\right.$, Sigma-Aldrich, $\left.>98 \%\right)$, lithium hydroxide monohydrate ( $\mathrm{LiOH} . \mathrm{H}_{2} \mathrm{O}$, Sigma-Aldrich, 97\%), lithium acetate dihydrate $\left(\mathrm{CH}_{3} \mathrm{COOLi} .2 \mathrm{H}_{2} \mathrm{O}\right.$, Sigma-Aldrich, $\left.>98 \%\right)$, Lithium phosphate $\left(\mathrm{Li}_{3} \mathrm{PO}_{4}\right.$, Sigma-Aldrich, $\left.97 \%\right)$, phosphoric acid $\left(\mathrm{H}_{3} \mathrm{PO}_{4}\right.$, Sigma-Aldrich, $68 \%$ in water) and hydrazine monohydrate $\left(\mathrm{N}_{2} \mathrm{H}_{4} \cdot \mathrm{H}_{2} \mathrm{O}\right.$, Sigma-Aldrich, $78-82 \%$ in water). $\mathrm{VPO}_{4}$ being not commercially available, it was prepared, as previously reported $^{22}$, through a carbothermal route by ball milling stoichiometric amounts of $\mathrm{V}_{2} \mathrm{O}_{5}$ and ammonium dihydrogen-phosphate $\left(\mathrm{NH}_{4} \mathrm{H}_{2} \mathrm{PO}_{4}\right.$, SigmaAldrich, $>99 \%$ ) together with an excess of highly divided carbon (Csp) (15 wt\%). This carbon acts as reducing agent of $\mathrm{V}^{5+}$ to $\mathrm{V}^{3+}$ and the remaining amount should enhance the electronic conductivity of the final product. Then, performing a thermal treatment under argon flow at $800^{\circ} \mathrm{C}$ during $8 \mathrm{~h}, \mathrm{C}-\mathrm{VPO}_{4}$ compound was obtained.

High Resolution Scanning Electron Microscopy (SEM) analysis of the samples' morphology was performed using a Hitachi S-4500 microscope. The powders were previously metallized by gold deposition. 
Diffraction data were collected using different instruments in order first to perform a phase analysis and to qualify the purity of the samples, and then to determine their structures: Laboratory X-ray diffraction (XRD) was performed on a PANalytical Empyrean diffractometer using the $\mathrm{Cu} \mathrm{K \alpha _{1 }}$ radiation, in the $\left[8-130^{\circ}\right]$ angular range with $0.0167^{\circ}(2 \theta)$ steps and for a total accumulation time of $24 \mathrm{~h}$. High resolution Synchrotron powder X-ray diffraction (SXRD) data were collected using the MSPD diffractometer at ALBA (Barcelona, Spain ${ }^{40}$ ), in DebyeScherrer geometry at $0.4959 \AA$ in the $2 \theta$ angular range of $1^{\circ}-53^{\circ}$ with a $0.006^{\circ}(2 \theta)$ step and an accumulation time of 5 minutes. The sample was sealed in a $0.7 \mathrm{~mm}$ diameter capillary. Neutron diffraction (ND) was performed on the same samples at the Institut Laue Langevin (ILL, Grenoble, France) on the high-resolution diffractometer D2B. The samples were not enriched in deuterium to minimize the incoherent scattering, it could explain the high value obtained for the isotropic Debye-Waller factor (Biso) associated with the $H(1)$ site (i.e. 8.5(3). The samples were contained in an $8 \mathrm{~mm}$ diameter vanadium tube, and the diffraction patterns were collected in transmission mode at room temperature, with a wavelength of $1.5935 \AA$ in the $2 \theta$ angular range of $\left[0-150^{\circ}\right]$ using a $0.05^{\circ}(2 \theta)$ step with a global accumulation time of $12 \mathrm{~h}$. It was necessary to correct the absorption in order to take into account a decrease of the experimental diffracted intensity compared to the expected one. The calculated absorption correction coefficient $(\mu \mathrm{R}$ factor in the FullProf program with $\mu$ $\left(=1.76 \mathrm{~cm}^{-1}\right)$ the linear absorption of the compound and $\mathrm{R}$ the radius of the vanadium tube) is equal to 0.70. Diffraction data treatment, Rietveld refinement and Bond Valence Energy Landscape were performed using the FullProf Suite ${ }^{41}$.

The chemical compositions of the samples ( $\mathrm{Li}, \mathrm{V}$, and $\mathrm{P}$ contents) were confirmed by using an Inductively Coupled Plasma / Optical Emission Spectrometry (ICP-OES) spectrometer (Varian 720-ES Optical Emission Spectrometer) after complete dissolution of the powders into a mixture of hydrochloric-nitric acid solution

In order to characterize further the structure and to evidence the presence of hydroxyl groups, infrared spectroscopy measurements were performed in the range of $400-4000 \mathrm{~cm}^{-1}$ (mid-IR) using a FTIR Nicolet 6700 (Thermo Scientific) equipped with a DTGS detector and a diffuse reflectance accessory. The samples were finely ground in a mortar with dried $\mathrm{KBr}$, the mass ratio between active material and $\mathrm{KBr}$ being approximately 1:50. 
Finally, reflectance spectra were treated with the Kubelka-Munk law, which converts the reflectance to a signal proportional to the absorption coefficient.

In order to further confirm the composition and crystal structure of $\mathrm{LiVPO}_{4} \mathrm{OH}$, magic angle spinning nuclear magnetic resonance (MAS NMR) was performed. ${ }^{1} \mathrm{H}$ and ${ }^{7} \mathrm{Li}$ MAS NMR spectra were recorded on a Bruker Avance spectrometer with a 7T magnet (116 MHz resonance frequency for ${ }^{7} \mathrm{Li}$ and $300 \mathrm{MHz}$ for ${ }^{1} \mathrm{H}$ ), using a standard Bruker $2.5 \mathrm{MAS}$ probe at a $30 \mathrm{kHz}$ spinning frequency. A Hahn echo sequence was applied with a $90^{\circ}$ pulse of $1.2 \mu \mathrm{s}$ for both probed nuclei. The relaxation time (D1) was respectively set to $1 \mathrm{~s}$ and $100 \mathrm{~s}$ for ${ }^{1} \mathrm{H}$ and ${ }^{7} \mathrm{Li}$. A $1 \mathrm{M} \mathrm{LiCl}$ aqueous solution and $\mathrm{H}_{2} \mathrm{O}$ were used as $0 \mathrm{ppm}$ external references for ${ }^{7} \mathrm{Li}$ and ${ }^{1} \mathrm{H}$ respectively. ${ }^{31} \mathrm{P}$ MAS NMR spectra were recorded on a Bruker Avance III spectrometer with a 2.35T magnet (40.6 MHz Larmor frequency), a standard Bruker 2.5 MAS probe at a 30 $\mathrm{kHz}$ spinning frequency. A Hahn echo sequence was used with a $90^{\circ}$ pulse of $1.2 \mu \mathrm{s}$ with a relaxation time of $1 \mathrm{~s}$. The $0 \mathrm{ppm}$ external reference was a $1 \mathrm{M} \mathrm{H}_{3} \mathrm{PO}_{4}$ aqueous solution.

To determine the electrochemical properties of a $\mathrm{LiVPO}_{4} \mathrm{OH}$ sample in laboratory lithium cells, electrodes were prepared using 85 wt\% of carbon coated $\mathrm{LiVPO}_{4} \mathrm{OH}, 5 \mathrm{wt} \%$ of carbon (Super P) and $10 \mathrm{wt} \%$ of polyvinylidene fluoride (PVDF). Taking into account the total carbon content (as a coating in the active material and as conductive additive in the electrode) the effective composition of the electrode was 70/20/10 in mass ratio for active material/carbon/PVDF. N-methyl pyrrolidinone was added to this mixture and the resultant slurry was cast on an Al foil and dried at $60^{\circ} \mathrm{C}$ during $24 \mathrm{~h}$. Discs (diameter $12 \mathrm{~mm}$ ) cut in this foil were cycled in coin cells vs. metallic Lithium in galvanostatic intermittent titration technique (GITT) mode at a rate of $\mathrm{C} / 100$ per ion (i.e. corresponding to the exchange of one electron in 100 hours) with a relaxation condition such as $\mathrm{dV} / \mathrm{dt} \leq 4 \mathrm{mV} / \mathrm{h}$. The electrolyte used was a $1 \mathrm{M}$ solution of $\mathrm{LiPF}_{6}$ in ethylene carbonate and dimethyl carbonate in a 1:1 volume ratio (LP30). Lithium cells were cycled, either in the high voltage domain between 3.0 and 4.4V vs $\mathrm{Li}^{+} / \mathrm{Li}$ or in the low voltage domain between 3.0 and $1.2 \mathrm{~V} \mathrm{vs} \mathrm{Li}^{+} / \mathrm{Li}$. In order to get information on the phases formed during the extraction reaction (i.e. oxidation of $V^{\prime \prime \prime}$ to $\mathrm{V}^{\mathrm{IV}}$ and possibly $\mathrm{V}^{\mathrm{IV}}$ to $\mathrm{V}^{\mathrm{V}}$ ) and during the intercalation reaction (i.e. reduction of $\mathrm{V}^{\prime \prime \prime}$ to $\mathrm{V}^{\prime \prime}$ ) from/in the pristine material $\mathrm{LiV}^{\prime \prime \prime} \mathrm{PO}_{4} \mathrm{OH}$, ex-situ XRD was performed at the end of the first charge and discharge. Materials were prepared by directly depositing $\sim 20 \mathrm{mg}$ of active 
material in swagelok cells. These cells were cycled at C/100 per ion and a floating (until I < $1 \mu \mathrm{A}$ ) was performed when the cut-off voltage was reached (at $4.4 \mathrm{~V}$ in charge and at $1.2 \mathrm{~V}$ in discharge), in order to overpass the kinetic limitations. The materials thus prepared were recovered under inert atmosphere in an argon filled glove box and sealed in a $0.7 \mathrm{~mm}$ diameter capillary to be analyzed by XRD using a PANalytical $X^{\prime}$ pert ${ }^{3}$ diffractometer (Cu K $\mathrm{K}_{\alpha 1,2}$ radiation, $2 \theta$ angular range of $\left[10-120^{\circ}\right]$ with a $2 \theta$ step of $0.0167^{\circ}$ and an acquisition duration of $14 h)$.

\section{Results and discussion}

\section{2a. Syntheses}

By analogy with hydrothermal syntheses already reported for other Tavorite type materials, $\mathrm{HV}^{\prime \prime \prime} \mathrm{PO}_{4} \mathrm{OH}$ (or $\left.\mathrm{VPO}_{4} \cdot \mathrm{H}_{2} \mathrm{O}\right)^{42}$, $\mathrm{LiFe}^{\prime \prime \prime} \mathrm{PO}_{4} \mathrm{OH}^{12}$ and $\mathrm{LiV}^{\mathrm{IV}} \mathrm{PO}_{4} \mathrm{O}^{43}$, we obtained the vanadium (III) hydroxy-phosphate $\mathrm{LiVPO}_{4} \mathrm{OH}$. Three different vanadium precursors were used, $\mathrm{V}^{\mathrm{III}} \mathrm{Cl}_{3}, \mathrm{~V}^{\mathrm{III}} \mathrm{PO}_{4}$ and $\mathrm{V}_{2}^{\mathrm{V}} \mathrm{O}_{5}$, according to the following conditions:

$$
\begin{aligned}
& \text { LVPH-a : } \mathbf{V C l}_{3}+1.40 \mathrm{Li}_{3} \mathrm{PO}_{4}+50 \mathrm{H}_{2} \mathrm{O}\left(240^{\circ} \mathrm{C}, 24 h\right) \\
& \text { LVPH-b : } \mathbf{C}-\mathrm{VPO}_{4}+2 \mathrm{CH}_{3} \mathrm{COOLi} .2 \mathrm{H}_{2} \mathrm{O}+100 \mathrm{H}_{2} \mathrm{O}\left(240^{\circ} \mathrm{C}, 24 h\right) \\
& \text { LVPH-c: } \mathbf{V}_{2} \mathrm{O}_{5}+1.5 \mathrm{~N}_{2} \mathrm{H}_{4} \cdot \mathrm{H}_{2} \mathrm{O}+3 \mathrm{H}_{3} \mathrm{PO}_{4}+6 \mathrm{LiOH} . \mathrm{H}_{2} \mathrm{O}+200 \mathrm{H}_{2} \mathrm{O}\left(250^{\circ} \mathrm{C}, 24 h\right)
\end{aligned}
$$

The precursors were introduced as such in $23 \mathrm{~mL}$ Teflon vessels filled at $\sim 60 \%$. The reactors were set in a furnace already at the temperature required for the thermal treatment, and were cooled down naturally until room temperature. The obtained powders were filtered, washed with water, rinsed with ethanol and dried at $60^{\circ} \mathrm{C}$ overnight. As expected, the reaction leading to formation of $\mathrm{LiVPO}_{4} \mathrm{OH}$ is driven by the basic $\mathrm{pH}$ of the starting solution (between 8 and 10), whereas moving to acidic solutions leads to the formation of $\mathrm{HVPO}_{4} \mathrm{OH}$. Indeed, the latter can be obtained from $\mathrm{VCl}_{3}$ by replacing $\mathrm{Li}_{3} \mathrm{PO}_{4}$ by $\mathrm{H}_{3} \mathrm{PO}_{4}$, or from $\mathrm{V}_{2} \mathrm{O}_{5}$ by replacing $\mathrm{H}_{3} \mathrm{PO}_{4}: \mathrm{LiOH} . \mathrm{H}_{2} \mathrm{O}$ by $\mathrm{H}_{3} \mathrm{PO}_{4}$ only. Nevertheless, all our attempts to obtain $\mathrm{HVPO}_{4} \mathrm{OH}$ directly from $\mathrm{LiVPO}_{4} \mathrm{OH}$ by $\mathrm{Li}^{+} / \mathrm{H}^{+}$ionic exchange in $\mathrm{HCl}$ aqueous solution failed, as for the 
reverse reaction (i.e. formation of $\mathrm{LiVPO}_{4} \mathrm{OH}$ from $\mathrm{HVPO}_{4} \mathrm{OH}$ ) in $\mathrm{LiOH}$ aqueous solution. On the contrary, Marx et al. reported the possibility of obtaining Tavorite type $\mathrm{HFePO}_{4} \mathrm{OH}$ by a $\mathrm{Li}^{+} / \mathrm{H}^{+}$ionic exchange within $\mathrm{LiFePO}_{4} \mathrm{OH}$ immersed in a nitric acid aqueous solution, whereas the reverse reaction was shown to occur in $\mathrm{LiOH}$ aqueous solution ${ }^{13}$.

The XRD patterns of the three samples thus obtained (LVPH-a, LVPH-b and LVPH-c) are compared in figure 1 to those of other Tavorite vanadium based compounds previously studied in our laboratories, $\mathrm{LiV}^{\mathrm{IV}} \mathrm{PO}_{4} \mathrm{O}, \mathrm{HV}^{\prime \prime \prime} \mathrm{PO}_{4} \mathrm{OH}$ and $\mathrm{LiV}^{\prime \prime \prime} \mathrm{PO}_{4} \mathrm{~F}$. They crystallize in Tavorite type structures described in triclinic $(\mathrm{P}-1)$ or monoclinic $\left(\mathrm{C} 2 / \mathrm{c}\right.$, for $\left.\mathrm{HV}^{\prime \prime \prime} \mathrm{PO} \mathrm{O}_{4} \mathrm{OH}\right)$ unit cells showing very close values for their volume per formula unit $(\mathrm{V} / \mathrm{Z})$, and thus similar but easily distinguishable XRD patterns. The XRD pattern of LVPH-a shows narrower diffraction peaks than those recorded for LVPH-b and LVPH-c, revealing a higher crystallinity. A careful inspection of these XRD data reveals also the presence of small amounts of impurities in each sample (as highlighted by $\nabla,{ }^{*}$ or \# in figure 1). The small intensity peaks observed at $2 \theta_{\mathrm{Cu}, \mathrm{Ka} \alpha}=16.3^{\circ}, 22.7^{\circ}, 24.9^{\circ}$ and $33.2^{\circ}$ for LVPH-a and at $2 \theta_{\mathrm{Cu}, \mathrm{K} \alpha 1}=20.4^{\circ}, 23.1^{\circ}$ and $24.9^{\circ}$ for LVPH-b cannot be indexed in Tavorite-type unit cells and were attributed to impurities we could not identify. Note that for LVPH-c the diffraction lines at $2 \theta_{\mathrm{Cu}, \mathrm{K \alpha} 1}=29.1^{\circ}, 33.8,35.2$ are obviously asymmetric, which could be explained considering a small amount of Tavorite $\mathrm{LiV}^{\mathrm{IV}} \mathrm{PO}_{4} \mathrm{O}$-like phase as impurity (as also supported by IR and NMR in the following). The cell parameters determined for the three $\mathrm{LiVPO}_{4} \mathrm{OH}$ powders are reported in table 2 and were found to be very similar, with for instance unit cell volumes of 175.04(1), 175.32(3) and 174.95(2) $\AA^{3}$ for $\mathrm{LiVPO}_{4} \mathrm{OH}$ in LVPH-a, LVPF-b and LVPF-c respectively. Thanks to ICP-AES chemical analyses, the molar ratios Li/V/P were determined for the three samples; they are given in table 2 and are in rather good agreement with the expected chemical formula $\mathrm{LiVPO}_{4} \mathrm{OH}$ (i.e. with $\left.1 \mathrm{Li}: 1 \mathrm{~V}: 1 \mathrm{P}\right)$, considering the presence of impurities in small amounts

The SEM images obtained for the three LVPH-a, LVPH-b and LVPH-c powders are given in figure 2. The primary particles of LVPH-a and LVPH-c are small platelets (smaller than 1.5 and $0.5 \mu \mathrm{m}$ in diameter respectively), those being agglomerated to form regular spheres of $20 \mu \mathrm{m}$ in diameter. The morphology of LVPH-b is different with bigger plateletlike primary particles (with a diameter of 1.5 to $3.0 \mu \mathrm{m}$ and a thickness of $0.5 \mu \mathrm{m}$ ). These primary particles are aggregated in larger agglomerates (50 to $100 \mu \mathrm{m}$ in diameter), with 
small grains of carbon (50-100 nm) in the grain boundaries coming from the excess of carbon used during the synthesis of the precursor $\mathrm{C}^{-\mathrm{VPO}_{4}}$. This amount of carbon was determined by TGA analysis (given as figure S1 in the supplementary information) to be around 14.9 $w t \%$, i.e. similar to that initially present in the precursor. The difference of morphology between LVPH-a, LVPH-b and LVPH-c can partly be explained by a difference of solubility of the precursors used to obtain $\mathrm{LiVPO}_{4} \mathrm{OH}$. Indeed, LVPH-a and LVPH-c are synthetized from $\mathrm{VCl}_{3}$ or $\mathrm{V}_{2} \mathrm{O}_{5}$ which are soluble in the alkaline solution whereas the $\mathrm{VPO}_{4}$ precursor for LVPHb (with particle size around $50-100 \mu \mathrm{m}$ ) is insoluble at least until $240^{\circ} \mathrm{C}$. So, the two former materials are formed by nucleation of species in solution and then growth of small particles which agglomerate. On the contrary, for the latter, as $\mathrm{VPO}_{4}$ is not soluble, the nucleation of $\mathrm{LiVPO}_{4} \mathrm{OH}$ occurs at its surface, then the $\mathrm{Li}^{+}$and $\mathrm{HO}^{-}$ions diffuse inside the particle and the $\mathrm{LiVPO}_{4} \mathrm{OH}$ domains grow.

In the following, in-depth structural characterization from synchrotron and neutron diffraction data (SXRD and ND) is detailed for highly crystalline LVPH-a. For all samples Infrared and nuclear magnetic resonance spectroscopy were used as very efficient probes to evidence the formation of hydroxyl and vanadyle-type bonds and the nature of the impurities. Electrochemical tests are reported for LVPH-b that revealed better performances despite bigger primary particles and aggregates: the presence of carbon most probably improves the electronic percolation within the electrode for this polyanionic material with poor intrinsic transport properties, and the porosity of the aggregates allows their better wettability by the electrolyte.

\section{2b. Structural study}

The structure of this new $\mathrm{LiVPO}_{4} \mathrm{OH}$ Tavorite-like compound was solved using SXRD and ND combined refinements. Indeed, both diffraction techniques are required because vanadium is purely incoherent scatterer in ND and hydrogen and lithium to SXRD. SXRD pattern of LVPH-a can be indexed with a P-1 triclinic unit cell $(a=5.1335(1) \AA, b=5.3334(1)$ $\left.\AA, c=7.2824(2) \AA, \alpha=106.556(2)^{\circ}, \beta=109.217(2)^{\circ}, \gamma=97.352(2)^{\circ}, V / Z=87.484(6) \AA^{3}\right)$. Combined (ND and SXRD) Rietveld refinement was performed considering the structural model $(\mathrm{M}(1))_{1 b}(\mathrm{M}(2))_{1 c}\left\{(\mathrm{P})_{2 i}\left[\mathrm{O}_{2 i}\right]_{4}\right\} \mathrm{X}_{2 i}$ already used to describe $\mathrm{LiVPO}_{4} \mathrm{~F}^{15}$, first without taking 
into account lithium and hydrogen atoms. Bond valence sums (BVS) were calculated using the Zachariasen formula $\left[V_{i}=\Sigma_{j} s_{i j}=\sum \exp \left\{\left(d_{0}-d_{i j}\right) / 0.37\right\}\right]$ with the parameter $d_{0}$, which characterizes a typical cation-anion distance, taken from Brown et al. ${ }^{44}$ It allowed to determine which oxygen atom is linked to hydrogen to form an $\mathrm{OH}$ group: indeed the BVS value associated to the bridging oxygen atom was found to be smaller (0.97) than those of the four others (in average close to 1.75). This result is in agreement with the structure already reported for other existing Tavorite-like hydroxy-phosphate phases, with the hydroxyl groups bridging adjacent $\mathrm{MO}_{6}$ octahedra along the chains. Moreover, the BVS value determined for the two vanadium atoms was found close to 3 (2.93 and 3.00), in good agreement with the formation of $\mathrm{a} \mathrm{V}^{3+}$-rich phase. In order to determine the lithium and hydrogen atomic positions, Fourier difference maps were calculated, as described in details in $^{12}$ for $\mathrm{LiFePO}_{4} \mathrm{OH}$, to localize missing electronic density: two positions were detected around $(0.35,0.05,0.85)$ and $(0.25,0.60,0.70)$. The former was attributed to hydrogen since it is close to the bridging oxygen, and the latter to lithium as more inside the tunnels. Finally, combined Rietveld refinement was achieved considering the full description of the unit cell with all the atoms, lithium and hydrogen included. The comparison of the experimental and calculated diffraction data is given in figure 3 . The cell parameters, atomic positions and distances thus determined are given in table 3 and in table 4.

As illustrated in figure $4 \mathrm{a}$, the crystal structure of $\mathrm{LiVPO}_{4} \mathrm{OH}$ is built up by $\mathrm{VO}_{6}$ octahedra which share common oxygen atoms. Each bridging oxygen is also linked to a hydrogen atom so as to form $\cdots \mathrm{V} \cdots(\mathrm{OH}) \cdots \mathrm{V} \cdots(\mathrm{OH}) \cdots \mathrm{V} \cdots$ infinite chains running along $[001]_{\mathrm{P}-1}$. These chains of octahedra are connected to each other via $\mathrm{PO}_{4}$ tetrahedra forming

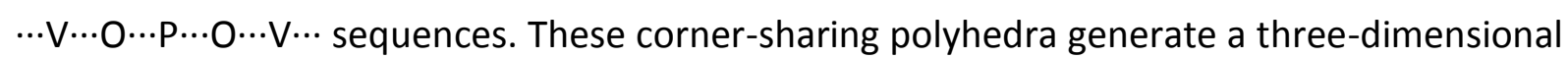
network within which lithium atoms occupy the tunnels along the $[100]_{P-1}$ direction. The phosphorus atom lies within a tetrahedron $\left(\Delta=3.65 \times 10^{-5}\right)$ with $\mathrm{P}-\mathrm{O}$ distances in the range of 1.53-1.56 ̊. Vanadium lies within two octahedral sites with a narrow range of $\mathrm{V}-\mathrm{O}$ distances, 1.99-2.04 $\AA, \mathrm{V}-\mathrm{OH}$ distances being of $2.03 \AA$ and $2.00 \AA$ for the octahedra centered on the $\mathrm{V}(1)$ and $\mathrm{V}(2)$ atoms respectively. The $\mathrm{V}(1) \mathrm{O}_{4}(\mathrm{OH})_{2}$ octahedron is slightly less distorted than the $\mathrm{V}(2) \mathrm{O}_{4}(\mathrm{OH})_{2}$ octahedron $\left(\Delta=1.35 \times 10^{-5}\right.$ and $\Delta=2.73 \times 10^{-5}$ respectively). A comparison with other Tavorite vanadium phosphate compositions is interesting as it allows to fully understand the nature of the bond observed along the chains of octahedra, 
depending on the bridging anion or on the anionic group. The $\mathrm{V}^{3+}$-rich compounds $\left(\mathrm{LiV}^{\mathrm{III}} \mathrm{PO}_{4} \mathrm{~F}\right.$, $\mathrm{LiV}^{\prime \prime \prime} \mathrm{PO}_{4} \mathrm{OH}$ and $\mathrm{HV}^{\prime \prime \prime} \mathrm{PO}_{4} \mathrm{OH}$ ) show constant bond lengths along their chains: shorter (1.98$1.99 \AA)$ for $V-F$, intermediate $(2.00-2.03 \AA)$ for $V-\{O H\}$, and longer $(2.15 \AA)$ for $V-\left\{\mathrm{OH}_{2}\right\}$, respectively. Note that for $\mathrm{LiV}^{\mathrm{IV}} \mathrm{PO}_{4} \mathrm{O}$, due to the presence of $\{\mathrm{VO}\}^{2+}$ vanadyle groups, there is an alternation between short and long bonds along the chains (1.67 and $2.19 \AA$ respectively). In fact, the more electronegative the bridging anion (or anionic group), the longer the $\mathrm{V}-\mathrm{X}$ distance is along the chains. The antagonistic bond to $\mathrm{V}-\mathrm{O}$ has to be considered as its covalency controls the structure thus stabilized: $\mathrm{O}-\mathrm{H}$ in $\cdots\{\mathrm{HO}\}-\mathrm{V}-\{\mathrm{OH}\} \cdots$ for $\mathrm{LiVPO}_{4} \mathrm{OH},(\mathrm{O}-$ $\mathrm{H})_{2}$ in ...\{ $\left.\mathrm{H}_{2} \mathrm{O}\right\}-\mathrm{V}-\left\{\mathrm{OH}_{2}\right\} \ldots$ for $\mathrm{HVPO}_{4} \mathrm{OH}$ and $\mathrm{V}=\mathrm{O}$ in ...\{O=V $\}-\mathrm{O} \ldots$ for $\mathrm{LiVPO}_{4} \mathrm{O}$. Indeed, their increasing covalency explains the increasing length of the antagonistic V-O bond in $\mathrm{LiVPO}_{4} \mathrm{OH}, \mathrm{HVPO}_{4} \mathrm{OH}$ and $\mathrm{LiVPO}_{4} \mathrm{O}$. Similarly, the length of the $\mathrm{V}-\mathrm{O}$ bond in these compounds is longer than $\mathrm{V}-\mathrm{F}$ in $\mathrm{LiVPO}_{4} \mathrm{~F}$, even if intrinsically $\mathrm{F}$ is more electronegative than $\mathrm{O}$.

The $\mathrm{O}(5)-\mathrm{H}$ bond length observed in $\mathrm{LiVPO}_{4} \mathrm{OH}$ is $1.06 \AA$, i.e. in the range of those already reported for the other Tavorite-like hydroxy-phosphate compounds (1.09 $\AA$ for $\mathrm{LiMnPO}_{4} \mathrm{OH}^{19}, 0.97 \AA$ for $\mathrm{LiFePO}{ }_{4} \mathrm{OH}^{12}$, and $0.85 \AA$ for $\mathrm{LiAlPO}_{4} \mathrm{OH}^{39}$ ). The longer the O(5)- $\mathrm{H}$ distance in $\mathrm{LiMPO}_{4} \mathrm{OH}$, the shorter is the distance between $\mathrm{H}$ and $\mathrm{O}(4)$ across the tunnel: it is $1.68 \AA$ in $\mathrm{LiMnPO}_{4} \mathrm{OH}, 1.80 \AA$ in $\mathrm{LiVPO}_{4} \mathrm{OH}, 1.86 \AA$ in $\mathrm{LiFePO}_{4} \mathrm{OH}$ and $2.06 \AA$ in $\mathrm{LiAlPO}_{4} \mathrm{OH}$.

The unique $\mathrm{Li}(1)$ site observed in $\mathrm{LiVPO}_{4} \mathrm{OH}$ is surrounded by five oxygen atoms, one of them being bonded to hydrogen, in a distorted $\mathrm{LiO}_{4}(\mathrm{OH})$ polyhedron with $\mathrm{Li}-\mathrm{O}$ distances ranging between 1.96 and $2.24 \AA\left(\Delta=1.79 \times 10^{-3}\right)$. The BVS value associated to $\mathrm{Li}(1)$ is close to 1 (i.e. 0.99). The anisotropic Debye-Waller factor ( $\left.B_{\text {aniso }}\right)$ associated with Lithium exhibits an ovoid shape elongated along the [10-1] direction, despite $\mathrm{Li}^{+}-\mathrm{Li}^{+}$distances larger than $10.2 \AA$ along this direction. In order to get more insights into the possible pathways for Lithium diffusion, the Bond Valence Energy Landscape (BVEL) was calculated thanks to the Bondstr software in the Fullprof suite. This empirical method uses Bond valence Sum to determine possible diffusion pathways considering a given energy to activate the movement of $\mathrm{Li}^{45}$. With $1.6 \mathrm{eV}$, BVEL highlights a zig-zag diffusion pathway along the [001] direction with $\mathrm{Li}^{+}$ ions moving from a large channel defined by an hexagonal section to another, going through intermediate smaller channels, defined by a "square" section whose diagonal is around 4.1 $\AA$. In fact, the elongation direction of $B_{\text {aniso }}$ points towards this "square" channel. Note that 
these results are different from those predicted by Mueller and coworker ${ }^{46}$ for Tavorite compounds, with a preferential diffusion pathway along the [111] direction in $\mathrm{VPO}_{4} \mathrm{~F}$. In our case, the hydroxyl group and the possible hydrogen bond between $\mathrm{O}(4)$ and $\mathrm{H}$ could hamper Lithium diffusion along the [111] direction, whereas this does not occur along the [001] direction (figure 4a).

This diffraction study reveals the formation of a new $\mathrm{LiVPO}_{4} \mathrm{OH}$ phase crystallizing in a Tavorite structure. Diffuse reflectance IR and MAS NMR were used to characterize further its structure and to confirm for instance the presence of a hydroxyl group.

\section{2c. Spectroscopic study}

FTIR

The Mid-IR diffuse reflectance spectra of LVPH-a, LVPH-b and LVPH-c are compared in figure 5. The assignment of the main vibrational signals is given in table 5 . The first information is the presence of a band at $3300 \mathrm{~cm}^{-1}$ matching with the stretching vibration of a hydroxyl group. This signature is clearly different from the $\mathrm{O}-\mathrm{H}$ stretching mode observed for the $\mathrm{H}-\mathrm{O}-\mathrm{H}$ group in $\mathrm{HVPO}_{4} \mathrm{OH}$, also written as $\mathrm{VPO}_{4} \cdot \mathrm{H}_{2} \mathrm{O}$. For this latter, the water molecule bridges two octahedra along the chains ${ }^{42}$ and the IR signature is a very broad band around $3000 \mathrm{~cm}^{-1}$ (inset figure 5) whereas for $\mathrm{LiVPO}_{4} \mathrm{OH}$ a narrower band is observed at higher wavenumber. The value of this wavenumber is typical for hydroxyl groups influenced by their environments, in good agreement with a possible hydrogen bond between $\mathrm{H}$ and $\mathrm{O}(4)$. Indeed, when the $\mathrm{OH}$ group is isolated the corresponding vibration appears as an even narrower band at a higher wavenumber (i.e. between 3500 and $3700 \mathrm{~cm}^{-1}{ }^{47}$ ). Nevertheless, the narrow profile of the band despite small difference in width indicates that the hydrogen bonds are quite weak for the three samples.

The $\mathrm{PO}_{4}$ stretching region, between 950 and $1200 \mathrm{~cm}^{-113,35}$, is very similar to those of the other vanadium based Tavorite compounds ${ }^{27}$, with three main bands around 988, 1041 and $1085 \mathrm{~cm}^{-1}$. The signature at lower wavenumber is attributed to the symmetric stretching mode of $\mathrm{PO}_{4}$ groups and the two others to the antisymmetric stretching vibrations. Theoretically, three antisymmetric modes must be observed but due to the small distortion 
of $\mathrm{PO}_{4}$ groups in this compound $\left(\Delta=3.6510^{-5}\right)$, the bands overlap does not allow to distinguish them (without Pseudo-Voigt deconvolution of the signal). In the case of an isolated symmetrical phosphate group, all antisymmetric stretching modes are equivalent. The amplitude of their splitting and thus the width of the signal can be related to the distortion of $\mathrm{PO}_{4}$ tetrahedra ${ }^{13}$. As the widths observed for the three samples are close, the distortion of $\mathrm{PO}_{4}$ tetrahedra is similar (note that the smaller size of the coherent domains in LVPH-b and LVPH-c can also induce a broadening of their whole spectra). Two additional bands, smaller in intensity, are observed at 950 and $1167 \mathrm{~cm}^{-1}$ for LVPH-b and LVPH-c (highlighted by $\nabla$ at the figure 5). These bands are typical of a $\mathrm{LiVPO}_{4} \mathrm{O}$-type environment $^{35,48}$.

Moreover, a tiny signal is observed at $891 \mathrm{~cm}^{-1}$ for LVPH-a. The same signal exists also for LVPH-b, with a higher intensity. The spectrum of LVPH-c exhibits a more shifted and broader signal at $902 \mathrm{~cm}^{-1}$ whose intensity is slightly larger than that observed for LVPH-b. This contribution around $891-902 \mathrm{~cm}^{-1}$ can be assigned to a vanadyle-type bond vibration ${ }^{49}$, i.e. to a short $\mathrm{V}=\mathrm{O}$ bond observed only for vanadium with an oxidation state larger than $3+$. Typically, for Tavorite $\mathrm{LiV}^{\mathrm{IV}} \mathrm{PO}_{4} \mathrm{O}$, the corresponding vibration is observed as a narrow peak at $907 \mathrm{~cm}^{-135}$. This signature reveals the presence of a LiVPO ${ }_{4} \mathrm{O}-$ like phase as impurity in the materials (especially in LVPH-b and LVPH-c), or the existence of vanadyle defects in the $\mathrm{LiVPO}_{4} \mathrm{OH}$ structure due to some local $\mathrm{LiVPO}_{4} \mathrm{O}$-type arrangement. The weaker wavenumber of the $\mathrm{V}=\mathrm{O}$ stretching mode (and so the weaker force constant or bond strength) highlights the formation of $\mathrm{V}=\mathrm{O}$ bonds longer than those observed in ideal $\mathrm{LiV}^{\mathrm{IV}} \mathrm{PO}_{4} \mathrm{O}$. Furthermore, the broad signal reveals a distribution of $\mathrm{V}=\mathrm{O}$ distances, and so a distribution of environments. By analogy with $\mathrm{LiFePO}_{4} \mathrm{OH}^{13}$, the band located at $829 \mathrm{~cm}^{-1}$ could be assigned to $\mathrm{V}-\mathrm{O}$ stretching vibration in $\mathrm{V}-\mathrm{O}-\mathrm{H}$ sequences. The region between 500 to $640 \mathrm{~cm}^{-1}$ and the region below $500 \mathrm{~cm}^{-1}$ (not shown here) gather bending modes of $\mathrm{PO}_{4}$ and $\mathrm{V}-\mathrm{O}$ polyhedra, vibrations involving $\mathrm{Li}-\mathrm{O}$ bonds and lattice modes. This last spectral range will not be discussed here.

The IR spectroscopy confirms the presence of the hydroxyl group influenced by hydrogen bond and highlights also a vanadyle-type contribution, slightly different for the three samples. In order to get more information on the nature and localisation of these 
vanadyle bonds, through their vicinity with ${ }^{7} \mathrm{Li},{ }^{31} \mathrm{P}$ and ${ }^{1} \mathrm{H}$, MAS NMR spectroscopy experiments were carried out.

\section{NMR}

The ${ }^{7} \mathrm{Li}$ MAS NMR spectra of the three samples (LVPH-a, LVPH-b and LVPH-c) are compared in figure 6a. They exhibit a main peak around $149 \mathrm{ppm}$, highlighted by \# and whose spinning side bands are identified by ${ }^{*}$, likely corresponding to the Lithium site in $\mathrm{LiVPO}_{4} \mathrm{OH}$. Additional shifted components are observed for the three samples: a series of additional small intensity peaks at 180, 97, 79, 58 and 25 ppm for the two samples LVPH-a and LVPH-b, and a single additional one at $70 \mathrm{ppm}$ for LVPH-c. 2D EXSY-RFDR ${ }^{7}$ Li MAS NMR experiments (see figure S2 and figure S3 in supplementary information) do not show any obvious dipolar connectivity between these additional signals and the main one at $149 \mathrm{ppm}$, showing that they correspond to Li ions not present in the same phase. This is also true for LVPH-b although the weaker magnitude of the additional signals makes it more difficult to distinguish possible cross-peaks. The spectra for the two samples LVPH-a and LVPH-b differ only in the intensity ratio of these additional small intensity signals, which are not likely to correspond to the impurities seen by XRD as these are crystallographically different for the two samples. Concerning LVPH-c, as discussed before, it contains a $\mathrm{LiVPO}_{4} \mathrm{O}$-like impurity that could correspond to the additional shifted ${ }^{7} \mathrm{Li}$ NMR component observed at $70 \mathrm{ppm}$. Considering that the ${ }^{7} \mathrm{Li}$ MAS NMR signal in $\mathrm{LiV}^{\mathrm{IV}} \mathrm{PO}_{4} \mathrm{O}$ is located at $80 \mathrm{ppm}^{50}$ we therefore suggest that structural defects, as also suggested by diffraction and IR spectroscopy and as observed in $\mathrm{LiVPO}_{4} \mathrm{~F}^{51}$, are present in the $\mathrm{LiVPO}_{4} \mathrm{O}$ impurity.

Coming back to the main signal of $\mathrm{LiVPO}_{4} \mathrm{OH}$ at $149 \mathrm{ppm}$, it is interesting to compare its position to those reported for other $\mathrm{M}^{3+}$ Tavorite-type compounds. All paramagnetic compounds (such as vanadium, iron and manganese based Tavorite-like compounds discussed in this section) lead to NMR spectra dominated by interactions between nuclear and electron spins (hyperfine interactions). The Fermi contact shift, which governs the position of the NMR signal of such compounds, corresponds to the presence of some density of electron spin at the nucleus probed. Indeed, the value of the Fermi contact shift is proportional to the spin density at the site of the probed nucleus and to the magnetic 
susceptibility of the compound ${ }^{52}$. The ${ }^{7} \mathrm{Li} \mathrm{NMR}$ shifts for $\mathrm{LiVPO}_{4} \mathrm{OH}, \mathrm{LiVPO}_{4} \mathrm{~F}^{51}, \mathrm{LiFePO}_{4} \mathrm{OH}^{53}$ and $\mathrm{LiMnPO}_{4} \mathrm{OH}^{54}$ are given in table 6. For all these phases, the lithium polyhedra share two edges and two corners with the $\mathrm{MO}_{4} \mathrm{X}_{2}$ octahedra (inset figure 6a). As discussed by Castets et $\mathrm{al}^{54}$, the spin transfer from vanadium to lithium can occur only from the $t_{2 \mathrm{~g}}$ orbitals for $\mathrm{V}^{3+}$ $\left(\mathrm{t}_{2 \mathrm{~g}}{ }^{2}\right)$ pointing toward the edges of the octahedra, i.e. via the common edges between the lithium and vanadium polyhedra. For the other $\mathrm{M}^{3+}$ Tavorite phases, this spin transfer can occur also from the $e_{g}$ orbitals which are not empty for $\mathrm{Mn}^{3+}\left(\mathrm{t}_{2 \mathrm{~g}}{ }^{3} \mathrm{e}_{\mathrm{g}}{ }^{1}\right)$ and $\mathrm{Fe}^{3+}\left(\mathrm{t}_{2 \mathrm{~g}}{ }^{3} \mathrm{e}_{\mathrm{g}}{ }^{2}\right)$, via the $2 p$ orbitals of the oxygen atoms shared between the polyhedra. This is fully consistent with the lowest contact shift observed for the $\mathrm{V}^{3+}$ phases.

The main information given by the ${ }^{1} \mathrm{H}$ MAS NMR spectra (figure $6 \mathrm{~b}$ ) is the presence of a shifted signal at $672 \mathrm{ppm}$ which may match with the only crystallographic site for the hydrogen atom, thus strengthening the observation made by neutron diffraction. A signal which matches with (diamagnetic) adsorbed water or surface hydroxyl group in the environment of the probe (sample, rotor or probe) is also observed close to $0 \mathrm{ppm}$. In the Tavorite structure, hydrogen is bonded to the oxygen which links two transition metal octahedra (inset figure 6b), and can therefore interact with both of them. As discussed by Castets et al., the spin transfer cannot occur from $\mathrm{e}_{\mathrm{g}}$ orbitals of the transition metal to the $1 \mathrm{~s}$ of hydrogen through the $2 \mathrm{p}_{\mathrm{z}}$ orbitals of oxygen because the $\mathrm{M}-\mathrm{O}-\mathrm{H}$ angles are far from $180^{\circ}$ $\left(96.7^{\circ}, 106.5^{\circ}\right.$, and $107.2^{\circ}$ for the iron, manganese and vanadium phases respectively). The only transfer possible is via a $\pi$ overlap of the $t_{2 g}$ and the 1 s of hydrogen via the $2 p$ of oxygen. However, as shown in table 6 , the ${ }^{1} \mathrm{H}$ shift for $\mathrm{LiVPO}_{4} \mathrm{OH}$ is larger than for $\mathrm{LiFePO}_{4} \mathrm{OH}$ that has more $t_{2 g}$ electron spins. But, as discussed just before, there are significant differences between the hydrogen local environments in Tavorite compounds; therefore, the resulting electron spin transfer needs to be modeled and analyzed in detail in each case to understand the relative magnitude of the ${ }^{1} \mathrm{H}$ NMR shifts in the series.

${ }^{31}$ P MAS NMR (figure 6c) was also performed and the main signal is located around 4300 ppm for all the samples. The spectra however exhibit several other peaks that cannot be attributed to spinning sidebands, mostly one at 2300 ppm for LVPH-a and a pair of peaks at 1480 and 1150 ppm for LVPH-c ; the latter appears to be also present but much weaker (and slightly shifted) in LVPH-a and LVPH-b. The ${ }^{31} \mathrm{P}$ shifts for the two P sites in $\mathrm{LiVPO}_{4} \mathrm{O}$ are 1418 and $1593 \mathrm{ppm}^{50}$. Therefore, following the ${ }^{7} \mathrm{Li}$ NMR observation discussed above, the 
observed signals in LVPH-c might result from $\mathrm{LiVPO}_{4} \mathrm{O}$ with defects as impurity, although the difference with ideal $\mathrm{LiVPO}_{4} \mathrm{O}$ appears to be rather large. Considering the main signal to be that of $\mathrm{P}$ in $\mathrm{LiVPO}_{4} \mathrm{H}$, we again compare its position with the Tavorite series in table 6 . As illustrated in figure $6 \mathrm{c}$, in the Tavorite structure, $\mathrm{PO}_{4}$ tetrahedra are connected to four different transition metal octahedra via the oxygen belonging to the square plane of these octahedra. As discussed by Castets et al., in $\mathrm{LiMPO}_{4} \mathrm{OH}$ the spin transfer to the $2 \mathrm{~s}$ (or the $\mathrm{sp}^{3}$ hybrid) orbital of Phosphorus can occur from the $t_{2 g}$ orbitals (via $\pi$ overlap with a $p$ orbital of oxygen), or from the $e_{g}$ orbitals via $\mathrm{O}$. Therefore, like in the case of ${ }^{7} \mathrm{Li}$ discussed above, the shift for $\mathrm{LiVPO}_{4} \mathrm{OH}$ is logically the lowest of the series ( $\mathrm{LiFePO}{ }_{4} \mathrm{OH}$ : 7498; $\mathrm{LiMnPO}_{4} \mathrm{OH}$ : 8483).

Thus, MAS NMR has evidenced the expected ${ }^{7} \mathrm{Li},{ }^{1} \mathrm{H}$ and ${ }^{31} \mathrm{P}$ signals for $\mathrm{LiVPO}_{4} \mathrm{OH}$, but also the presence of different additional signals, depending on the sample, the strongest of them (observed for $\mathrm{LVPH}-\mathrm{c}$ ) being attributed to the presence of $\mathrm{LiVPO}_{4} \mathrm{O}$ impurities exhibiting defects, in agreement with the diffraction results discussed above. Altogether, the spectroscopic study highlights the presence of hydroxyl group as bridging anion in this new Tavorite-type material. The nature of this bridging anion in Tavorite compounds greatly influences the working potential of such kind of material as reported before for iron, titanium and vanadium phases. Electrochemical tests were performed in order to demonstrate this influence.

\section{2d. Electrochemical properties vs. Li}

A flat voltage plateau is observed at $3.95 \mathrm{~V}$ vs $\mathrm{Li}^{+} / \mathrm{Li}$ during the first charge of $\mathrm{Li} / /$ $\mathrm{LiV}^{\text {IIIPO}}{ }_{4} \mathrm{OH}$ cells in GITT conditions up to $4.4 \mathrm{~V}$ (figure 7a). The capacity associated to this first charge $(280 \mathrm{mAh} / \mathrm{g})$ is almost twice larger than the theoretical one (158 $\mathrm{mAh} / \mathrm{g})$, considering only the extraction of lithium. From this result it is thus justified to consider the additional extraction of hydrogen as already observed for $\mathrm{HV}^{\text {III }} \mathrm{PO}_{4} \mathrm{OH}$ by Whittingham and coworkers $^{18}$ who showed that it was indeed possible to extract two hydrogen from $\mathrm{HVPO}_{4} \mathrm{OH}$ with the formation of the Tavorite phases $\mathrm{V}^{\vee} \mathrm{PO}_{4} \mathrm{O}$ at the end of the charge and $\mathrm{LiV}^{\mathrm{IV}} \mathrm{PO}_{4} \mathrm{O}$ at the end of the next discharge. Note also that for $\mathrm{LiVPO}_{4} \mathrm{OH}$, a large irreversible capacity is observed at the end of the discharge down to $3 \mathrm{~V} \mathrm{vs} \mathrm{Li}^{+} / \mathrm{Li}$ : it corresponds to about one electron per vanadium and could thus be associated to the insertion of Lithium. 
In order to get more insight into mechanisms involved upon oxidation, XRD experiments were performed ex-situ, i.e. recovering electrodes from batteries cycled at $\mathrm{C} / 100$ rate, to identify the nature of the phases formed at the end of the charge and at the end of the next discharge ( 2 and 3 respectively, as highlighted in figure 7a). As shown by the indexation of the XRD patterns given in figure 8 and by the corresponding cell parameters, $\mathrm{VPO}_{4} \mathrm{O}$ is obtained at the end of the first charge, and $\mathrm{LiVPO}_{4} \mathrm{O}$ at the end of the next discharge. Their structures were found to be in good agreement with those already reported in the literature with $\mathrm{V} / \mathrm{Z}$ values close to 81.98 and $85.51 \AA^{3}$ for $\mathrm{VPO}_{4} \mathrm{O}$ and $\mathrm{LiVPO}_{4} \mathrm{O}$ respectively ${ }^{36}$. A volume change of about $6.6 \%$ is observed for the polyanionic framework upon cycling in the high potential range. These results confirm that extraction of both lithium and hydrogen occurs, but surprisingly at the same equilibrium potential of $3.95 \mathrm{~V}$ vs. Li. It suggests thus that a concerted mechanism involving the exchange of two electrons per vanadium occurs: extraction of lithium should induce the formation of the intermediate phase $\mathrm{V}^{\mathrm{IV}} \mathrm{PO}_{4} \mathrm{OH}$ but this latter appears in fact to be metastable. Our hypothesis is that the $\mathrm{V}^{\mathrm{IV}}-\mathrm{O}-\mathrm{H}$ sequence is destabilized along the chains due to the competition between the antagonistic bonds: the vanadyle bond $(\mathrm{VO})^{2+}$ on one side and the hydroxyl bond $(\mathrm{OH})$ on the other side, that leads to a weakening of the latter $\left(\mathrm{V}^{\mathrm{IV}}-\mathrm{O}-\mathrm{H} \rightarrow \mathrm{V}=\mathrm{O} \cdots \mathrm{H}\right)$ and thus to the concomitant extraction of $\mathrm{Li}^{+}$and $\mathrm{H}^{+}$.

$\mathrm{LiV}^{\mathrm{III}} \mathrm{PO}_{4} \mathrm{OH}$ was also used in lithium cells in GITT conditions between 3.0 and $1.2 \mathrm{~V}$ vs $\mathrm{Li}^{+} / \mathrm{Li}$ (figure 7b). It is possible to insert almost one lithium per formula unit in $\mathrm{LiV}^{\prime \prime \prime} \mathrm{PO}{ }_{4} \mathrm{OH}$ to form $\mathrm{Li}_{2} \mathrm{~V}^{\prime \prime} \mathrm{PO}{ }_{4} \mathrm{OH}$ (4 in figures $7 \mathrm{~b}$ and 8 ). A reversible capacity of $136 \mathrm{mAh} / \mathrm{g}$ (vs. the theoretical capacity of $158 \mathrm{mAh} / \mathrm{g}$ ) is attained in the low potential range, with an irreversible capacity of around $10 \%$ and while $\mathrm{LiVPO}_{4} \mathrm{OH}$ is recovered at the end of the next charge (5 in figures $7 \mathrm{~b}$ and 8). The insertion of lithium in $\mathrm{LiVPO}_{4} \mathrm{OH}$ occurs according to a two-step mechanism: a solid solution process first leads to the formation of an intermediate phase with the composition $\sim \mathrm{Li}_{1.25} \mathrm{VPO}_{4} \mathrm{OH}$, and a biphasic reaction is then be observed at an

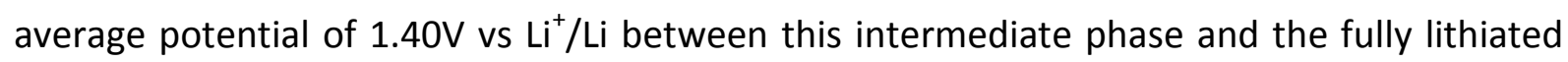
phase $\mathrm{Li}_{2} \mathrm{~V}^{\prime \prime} \mathrm{PO}_{4} \mathrm{OH}$. Note that the equilibrium is reached faster for Lithium intercalation (in about 1 hour) in $\mathrm{LiVPO}_{4} \mathrm{OH}$ than for Lithium extraction (in about 4 hours). 
The XRD pattern of the fully reduced phase $\mathrm{Li}_{2} \mathrm{~V}^{\prime \prime} \mathrm{PO}{ }_{4} \mathrm{OH}$ can be refined, considering the presence of $\mathrm{Li}_{1-\mathrm{x}} \mathrm{VPO}_{4} \mathrm{OH}$ as a secondary phase, in a triclinic unit cell described in the P-1 space group with the lattice parameters: $a=7.284(2) \AA, b=7.573(2) \AA, c=7.977(2) \AA, \alpha=$ $89.77(2)^{\circ}, \beta=88.05(2)^{\circ}, \gamma=118.71(2)^{\circ}, V=385.6(2) \AA$ and $V / Z=96.4(2) \AA^{3}$. Its cell volume is very large compared to that of the pristine material $\left(V / Z=87.7 \AA^{3}\right)$ with a volume expansion of $9.9 \%$, but it is in very good agreement with the structure already reported for the homotypic Tavorite $\mathrm{Li}_{2} \mathrm{~V}^{\prime \prime} \mathrm{PO}_{4} \mathrm{~F}$ with $\mathrm{V} / \mathrm{Z}=93.8 \AA^{329}$. $\mathrm{LiVPO}_{4} \mathrm{OH}$ recovered the end of the first cycle performed at low voltage is found to be very similar to the pristine phase, in good agreement with the satisfactory reversibility of the reaction.

Note that a careful inspection of the voltage vs composition data reveals also the presence of several shoulders at 2.452 .20 and $2.00 \mathrm{~V} \mathrm{vs} \mathrm{Li}^{+} / \mathrm{Li}$ (better highlighted considering the derivative curve given in inset of figure $7 \mathrm{~b}$ ). These potentials values match with those corresponding to lithium insertion $(2.45,2.20$ and $2.00 \mathrm{~V})$ in the Tavorite $\mathrm{LiV}^{\mathrm{IV}} \mathrm{PO}_{4} \mathrm{O}$, that was indeed revealed to be present as an impurity by ${ }^{7} \mathrm{Li}$ NMR and IR spectroscopy.

\section{Conclusion}

A vanadium based hydroxy-phosphate of Tavorite-type structure was obtained for the first time, by hydrothermal route at $\sim 250^{\circ} \mathrm{C}$. It could be prepared from three different vanadium precursors $\left(\mathrm{VCl}_{3}, \mathrm{~V}_{2} \mathrm{O}_{5}\right.$ and $\left.\mathrm{VPO}_{4}\right)$, always as the main phase but with different types of impurities. Most of them were in negligible amounts, and thus not identified. Nevertheless, a Tavorite type impurity, close but different to $\mathrm{LiVPO}_{4} \mathrm{O}$, was also obtained in particular when $\mathrm{V}_{2} \mathrm{O}_{5}$ was used as precursor. Diffuse reflectance IR spectroscopy and solid state MAS NMR $\left({ }^{1} \mathrm{H},{ }^{7} \mathrm{Li},{ }^{31} \mathrm{P}\right)$ appeared to be techniques of choice to prove the formation of a phase with hydroxyl groups. Electrochemical tests reveal original properties in the high voltage region. During the charge of $\mathrm{LiV}^{\prime \prime \prime} \mathrm{PO}_{4} \mathrm{OH}, \mathrm{Li}^{+}$and $\mathrm{H}^{+}$are extracted from the structure

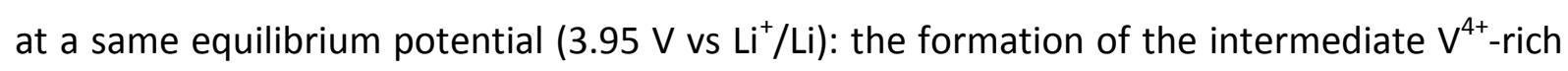
phase is not observed whereas $\mathrm{VPO}_{4} \mathrm{O}$ is obtained at the end of the charge. This system illustrates perfectly one possible track to follow to develop two-electron reactions at the same potential, playing with the stability of the antagonist bond in order to promote the 
concomitant and reversible extraction and reinsertion of two alkalis. It is worth also to consider this system versus reversible $\mathrm{H}^{+}$deintercalation and reintercalation in aqueous systems. In the low voltage region, a more conventional behavior is observed with the reversible insertion/extraction of Lithium at $1.40 \mathrm{~V} \mathrm{vs} \mathrm{Li}^{+} / \mathrm{Li}$ and the formation of $\mathrm{Li}_{2} \mathrm{VPO}_{4} \mathrm{OH}$ at the end of the discharge.

\section{Acknowledgment}

The authors thank Cathy Denage, Philippe Dagault and Laetitia Etienne at ICMCB and Matthieu Courty at LRCS for technical assistance, as well as ILL (Grenoble, France) for the beam time granted on the D2B high resolution neutron diffractometer and ALBA (Barcelona, Spain) for Synchrotron X-ray diffraction experiments on MSPD beamline. The authors also acknowledge FEDER, the Région Picardie and the RS2E Network for the funding of EB's PhD thesis, as well as the financial support of Région Aquitaine and of the French National Research Agency (STORE-EX Labex Project ANR-10-LABX-76-01 and HIPOLITE Progelec project ANR-12-PRGE-0005-02).

\section{References}

(1) Mizushima, K.; Jones, P. C.; Wiseman, P. J.; Goodenough, J. B. Lix $\mathrm{CoO}_{2}(0<\mathrm{X} \sim 1)$ : A NEW CATHODE MATERIAL FOR BATTERIES OF HIGH ENERGY DENSITY. Solid State Ionics 1981, 4, 171-174.

(2) Guilmard, M.; Pouillerie, C.; Croguennec, L.; Delmas, C. STRUCTURAL AND ELECTROCHEMICAL PROPERTIES OF $\mathrm{LiNi}_{0.70} \mathrm{Co}_{0.15} \mathrm{Al}_{0.15} \mathrm{O}_{2}$. Solid State Ionics 2003, 160 (1-2), 39-50. 
(3) Koyama, Y.; Tanaka, I.; Adachi, H.; Makimura, Y.; Ohzuku, T. CRYSTAL AND ELECTRONIC STRUCTURES OF SUPERSTRUCTURAL Li $i_{1-\mathrm{x}}\left[\mathrm{Co}_{1 / 3} \mathrm{Ni}_{1 / 3} \mathrm{Mn}_{1 / 3}\right] \mathrm{O}_{2}(0 \leq \mathrm{X} \leq 1)$. J. Power Sources 2003, 119-121, 644-648.

(4) Bang, H. J.; Joachin, H.; Yang, H.; Amine, K.; Prakash, J. CONTRIBUTION OF THE STRUCTURAL CHANGES OF $\mathrm{LiNi}_{0.8} \mathrm{CO}_{0.15} \mathrm{Al}_{0.05} \mathrm{O}_{2}$ CATHODES ON THE EXOTHERMIC REACTIONS IN LI-ION CELLS. J. Electrochem. Soc. 2006, 153 (4), A731.

(5) Padhi, A. K.; Nanjundaswamy, K. S.; Goodenough, J. B. PHOSPHO-OLIVINES AS POSITIVE-ELECTRODE MATERIALS FOR RECHARGEABLE LITHIUM BATTERIES. J. Electrochem. Soc. 1997, 144 (4), 2-8.

(6) Masquelier, C.; Croguennec, L. POLYANIONIC (PHOSPHATES, SILICATES, SULFATES) FRAMEWORKS AS ELECTRODE MATERIALS FOR RECHARGEABLE LI (OR NA) BATTERIES. Chem. Rev. 2013, 113 (8), 6552-6591.

(7) Muldoon, J.; Bucur, C. B.; Gregory, T. QUEST FOR NONAQUEOUS MULTIVALENT SECONDARY BATTERIES: MAGNESIUM AND BEYOND. Chem. Rev. 2014, 114 (23), $11683-11720$.

(8) Gong, Z.; Yang, Y. RECENT ADVANCES IN THE RESEARCH OF POLYANION-TYPE CATHODE MATERIALS FOR LI-ION BATTERIES. Energy Environ. Sci. 2011, 4 (9), 3223.

(9) Ellis, B. L.; Town, K.; Nazar, L. F. NEW COMPOSITE MATERIALS FOR LITHIUM-ION BATTERIES. Electrochim. Acta 2012, 84, 145-154. 
(10) Manthiram, A.; Goodenough, J. B. LITHIUM INSERTION INTO $\mathrm{Fe}_{2}\left(\mathrm{MO}_{4}\right)_{3}$ FRAMEWORKS: COMPARISON OF M = W WITH M = Mo. J. Solid State Chem. 1987, 71, $349-360$.

(11) Manthiram, A.; Goodenough, J. B. Journal of Power Sources. LITHIUM INSERTION INTO $\mathrm{Fe}_{2}\left(\mathrm{SO}_{4}\right)_{3}$ FRAMEWORK. 1989, 26, 403-408.

(12) Marx, N.; Croquennec, L.; Cartier, D.; Wattiaux, A.; Le Cras, F.; Suard, E.; Delmas, C. THE STRUCTURE OF TAVORITE LiFePO $_{4}(\mathrm{OH})$ FROM DIFFRACTION AND GGA $+U$ STUDIES AND ITS PRELIMINARY ELECTROCHEMICAL CHARACTERIZATION. Dalton Trans. 2010, 39 (21), 5108-5116.

(13) Marx, N.; Croguennec, L.; Carlier, D.; Bourgeois, L.; Kubiak, P.; Cras, F. Le; Delmas, C. STRUCTURAL AND ELECTROCHEMICAL STUDY OF A NEW CRYSTALLINE HYDRATED IRON(III) PHOSPHATE FePO $4 \cdot \mathrm{H}_{2} \mathrm{O}$ OBTAINED FROM LIFePO $(\mathrm{OH})$ BY ION EXCHANGE. Chem. Mater. 2010, 22 (5), 1854-1861.

(14) Ellis, B. L.; Ramesh, T. N.; Davis, L. J. M.; Goward, G. R.; Nazar, L. F. STRUCTURE AND ELECTROCHEMISTRY OF TWO-ELECTRON REDOX COUPLES IN LITHIUM METAL FLUOROPHOSPHATES BASED ON THE TAVORITE STRUCTURE. Chem. Mater. 2011, 23 (23), 5138-5148.

(15) Ateba Mba, J.; Masquelier, C.; Suard, E.; Croguennec, L. SYNTHESIS AND CRYSTALLOGRAPHIC STUDY OF HOMEOTYPIC LiVPO ${ }_{4} \mathrm{~F}$ AND LiVPO ${ }_{4} \mathrm{O}$. Chem. Mater. 2012, 24, 1223-1234. 
(16) Recham, N.; Chotard, J.-N.; Jumas, J.-C.; Laffont, L.; Armand, M.; Tarascon, J.-M. IONOTHERMAL SYNTHESIS OF LI-BASED FLUOROPHOSPHATES ELECTRODES. Chem. Mater. 2010, 22 (3), 1142-1148.

(17) Rousse, G.; Tarascon, J. M. SULFATE-BASED POLYANIONIC COMPOUNDS FOR LI-ION BATTERIES: SYNTHESIS, CRYSTAL CHEMISTRY, AND ELECTROCHEMISTRY ASPECTS. Chem. Mater. 2014, 26 (1), 394-406.

(18) Song, Y.; Zavalij, P. Y.; Whittingham, M. S. E-VOPO 4 : ELECTROCHEMICAL SYNTHESIS AND ENHANCED CATHODE BEHAVIOR. J. Electrochem. Soc. 2005, 152 (4), A721.

(19) Yang, Y.; Hirayama, M.; Yonemura, M.; Kanno, R. SYNTHESIS, CRYSTAL STRUCTURE, AND ELECTRODE CHARACTERISTICS OF $\mathrm{LIMnPO}_{4}(\mathrm{OH})$ CATHODE FOR LITHIUM BATTERIES. J. Solid State Chem. 2012, 187, 124-129.

(20) Mueller, T.; Hautier, G.; Jain, A.; Ceder, G. EVALUATION OF TAVORITE-STRUCTURED CATHODE MATERIALS FOR LITHIUM-ION BATTERIES USING HIGH-THROUGHPUT COMPUTING. Chem. Mater. 2011, 23 (17), 3854-3862.

(21) Patoux, S.; Masquelier, C. LITHIUM INSERTION INTO TITANIUM PHOSPHATES, SILICATES, AND SULFATES. Chem. Mater. 2002, 14, 5057-5068.

(22) Barker, J.; Saidi, M. Y.; Swoyer, J. L. ELECTROCHEMICAL INSERTION PROPERTIES OF THE NOVEL LITHIUM VANADIUM FLUOROPHOSPHATE, LIVPO ${ }_{4} \mathrm{~F}$. J. Electrochem. Soc. 2003, 150 (10), A1394. 
(23) Wang, Y.; Zhao, H.; Ji, Y.; Wang, L.; Wei, Z. LONG-LIFE AND HIGH-RATE LiVPO ${ }_{4} F / C$ NANOCRYSTALS MODIFIED WITH GRAPHENE AS CATHODE MATERIAL FOR LITHIUMION BATTERIES. Solid State Ionics 2014, 268, 169-173.

(24) Liu, Z.; Peng, W.; Fan, Y.; Li, X.; Wang, Z.; Guo, H.; Wang, J. A NEW ROUTE FOR GRAPHENE WRAPPING LIVPO $_{4} \mathrm{~F} / \mathrm{C}$ NANO COMPOSITE TOWARD SUPERIOR LITHIUM STORAGE PROPERTY. J. Alloys Compd. 2015, 639, 496-503.

(25) Kim, M.; Lee, S.; Kang, B. FAST-RATE CAPABLE ELECTRODE MATERIAL WITH HIGHER ENERGY DENSITY THAN LiFePO 4 : 4.2V LIVPO $_{4} F$ SYNTHESIZED BY SCALABLE SINGLESTEP SOLID-STATE REACTION. Adv. Sci. 2015, 1-9.

(26) Li, P.; Ma, R.; Lin, X.; Shao, L.; Wu, K.; Shui, M.; Long, N.; Shu, J. IMPACT OF $\mathrm{H}_{2} \mathrm{O}$ EXPOSURE ON THE STRUCTURE AND ELECTROCHEMICAL PERFORMANCE OF LIVPO ${ }_{4} \mathrm{~F}$ CATHODE MATERIAL. J. Alloys Compd. 2015, 637, 20-29.

(27) Ma, R.; Shao, L.; Wu, K.; Shui, M.; Wang, D.; Long, N.; Ren, Y.; Shu, J. EFFECTS OF OXIDATION ON STRUCTURE AND PERFORMANCE OF LIVPO ${ }_{4} F$ AS CATHODE MATERIAL FOR LITHIUM-ION BATTERIES. J. Power Sources 2014, 248, 874-885.

(28) Zhou, F.; Zhao, X.; Dahn, J. R. REACTIVITY OF CHARGED LiVPO ${ }_{4} F$ WITH $1 M$ LiPF 6 EC:DEC ELECTROLYTE AT HIGH TEMPERATURE AS STUDIED BY ACCELERATING RATE CALORIMETRY. Electrochem. commun. 2009, 11 (3), 589-591.

(29) Mba, J.-M. a.; Croguennec, L.; Basir, N. I.; Barker, J.; Masquelier, C. LITHIUM INSERTION OR EXTRACTION FROM/INTO TAVORITE-TYPE LIVPO ${ }_{4} F$ : AN IN SITU X-RAY DIFFRACTION STUDY. J. Electrochem. Soc. 2012, 159 (8), A1171-A1175. 
(30) Xiong, Z.; Zhang, G.; Xiong, J.; Yang, X.; Zhang, Y. MODIFIED SOL-GEL SYNTHESIS OF NANOSIZED LIVPO ${ }_{4}$ F/C CATHODE MATERIAL WITH MECHANICAL BLENDING ASSIST. Mater. Lett. 2013, 111, 214-216.

(31) Li, Y.; Zhou, Z.; Gao, X. P.; Yan, J. A NOVEL SOL-GEL METHOD TO SYNTHESIZE NANOCRYSTALLINE LIVPO ${ }_{4} F$ AND ITS ELECTROCHEMICAL LI INTERCALATION PERFORMANCES. J. Power Sources 2006, 160 (1), 633-637.

(32) Zhong, S.; Chen, W.; Li, Y.; Zou, Z.; Liu, C. SYNTHESIS OF LiVPO ${ }_{4} F$ WITH HIGH ELECTROCHEMICAL PERFORMANCE BY SOL-GEL ROUTE. Trans. Nonferrous Met. Soc. China 2010, 20, 275-278.

(33) Wang, J.; Wang, Z.; Li, X.; Guo, H.; Xiao, W.; Huang, S.; He, Z. COMPARATIVE INVESTIGATIONS OF LiVPO ${ }_{4} \mathrm{~F} / \mathrm{C}$ AND $\mathrm{Li}_{3} \mathrm{~V}_{2}\left(\mathrm{PO}_{4}\right)_{3} / \mathrm{C}$ SYNTHESIZED IN SIMILAR SOFT CHEMICAL ROUTE. J. Solid State Electrochem. 2012, 17 (1), 1-8.

(34) Wang, J.; Li, X.; Wang, Z.; Guo, H.; Zhang, Y.; Xiong, X.; He, Z. SYNTHESIS AND CHARACTERIZATION OF LIVPO ${ }_{4}$ F/C USING PRECURSOR OBTAINED THROUGH A SOFT CHEMICAL ROUTE WITH MECHANICAL ACTIVATION ASSIST. Electrochim. Acta 2013, $91,75-81$.

(35) Harrison, K. L.; Manthiram, A. MICROWAVE-ASSISTED SOLVOTHERMAL SYNTHESIS AND CHARACTERIZATION OF VARIOUS POLYMORPHS OF LiVOPO 4 . chemisrty Mater. 2013, 25, 1751-1760.

(36) Bianchini, M.; Ateba-Mba, J. M.; Dagault, P.; Bogdan, E.; Carlier, D.; Suard, E.; Masquelier, C.; Croguennec, L. MULTIPLE PHASES IN THE E-VPO ${ }_{4} \mathrm{O}-\mathrm{LiVPO}_{4} \mathrm{O}-\mathrm{Li}_{2} \mathrm{VPO}_{4} \mathrm{O}$ 
SYSTEM: A COMBINED SOLID STATE ELECTROCHEMISTRY AND DIFFRACTION STRUCTURAL STUDY. J. Mater. Chem. A 2014, 2 (26), 10182.

(37) Barker, J.; Saidi, Y.; Swoyer, J. L. ALKALI/TRANSITION METAL HALO AND HYDROXYPHOSPHATES AND RELATED ELECTRODE ACTIVE MATERIALS. US Patent 6,777,132 B2, Aug 172004.

(38) Chumein B. Phd Thesis. SYNTHESIS AND CHARACTERIZATION OF NANO-SCALE VANADIUM OXIDES, VANADIUM PHOSPHATES AS CATHODES FOR LITHIUM BATTERIES, State Universty of New York, Binghamton University, 2008.

(39) Groat, A.; Chakoumakos, B. C.; Brouwer, D. H.; Hoffman, C. M.; Fyfe, C. A.; Morell, H.; Schultz, A. J. THE AMBLYGONITE ( LiAIPO $_{4} \mathrm{~F}$ ) -MONTEBRASITE ( $\mathrm{LIAIPO}_{4} \mathrm{OH}$ ) SOLID SOLUTION : A COMBINED POWDER AND SINGLE-CRYSTAL NEUTRON DIFFRACTION AND SOLID-STATE 6 LI MAS , CP MAS , AND REDOR NMR STUDY. Am. Mineral. 2003, $88,195-210$.

(40) Fauth, F.; Peral, I.; Popescu, C.; Knapp, M. THE NEW MATERIAL SCIENCE POWDER DIFFRACTION BEAMLINE AT ALBA SYNCHROTRON. Powder Diffr. 2013, 28, 360-370.

(41) Rodriguez-carvajal. RECENT ADVANCES IN MAGNETIC STRUCTURE DETERMINATION BY NEUTRON POWDER DIFFRACTION J. Neutron Powder Diffraction. Phys. B 1993, $192,55-69$.

(42) Vaughey, J. T.; Harrison, W. T. A.; Jacobson, A. J.; Goshorn, D. P.; Johnson, J. W.; Technol, B. C. SYNTHESIS , STRUCTURE , AND PROPERTIES OF TWO NEW VANADIUM ( 
II1 ) PHOSPHATES : $\mathrm{VPO}_{4}-\mathrm{H}_{2} \mathrm{O}$ AND $\mathrm{V}_{1.23}\left(\mathrm{PO}_{4}\right)(\mathrm{OH})_{0.69}\left(\mathrm{H}_{2} \mathrm{O}\right)_{0.31} \cdot 0.33 \mathrm{H}_{2} \mathrm{O}$ Inorg. Chem. 1994, $23(8), 2481-2487$.

(43) Ren, M. M.; Zhou, Z.; Gao, X. P.; Liu, L.; Peng, W. X. LIVOPO 4 HOLlOW MICROSPHERES : ONE-POT HYDROTHERMAL SYNTHESIS WITH REACTANTS AS SELFSACRIFICE TEMPLATES AND LITHIUM INTERCALATION PERFORMANCES. J. Phys. Chem. C 2008, 13043-13046.

(44) Brown, I. D.; Altermatt, D. BOND-VALENCE PARAMETERS OBTAINED FROM A SYSTEMATIC ANALYSIS OF THE INORGANIC CRYSTAL STRUCTURE DATABASE I . Acta Cryst 1985, 41, 244-247.

(45) Adams, S. FROM BOND VALENCE MAPS TO ENERGY LANDSCAPES FOR MOBILE IONS IN ION-CONDUCTING SOLIDS. Solid State Ionics 2006, 177 (19-25), 1625-1630.

(46) Mueller, T.; Hautier, G.; Jain, A.; Ceder, G. EVALUATION OF TAVORITE-STRUCTURED CATHODE MATERIALS FOR LITHIUM-ION BATTERIES USING HIGH-THROUGHPUT COMPUTING. Chem. Mater. 2011, 23, 3854-3862.

(47) Nakamoto, K. INFRARED AND RAMAN SPECTRA OF INORGANIC AND COORDINATION COMPOUNDS. PART B: APPLICATIONS IN COORDINATION, ORGANOMETALLIC, AND BIOINORGANIC CHEMISTRY; John Wiley \& Sons, Inc., 1997; p 161.

(48) Yang, Y.; Fang, H.; Zheng, J.; Li, L.; Li, G.; Yan, G. TOWARDS THE UNDERSTANDING OF POOR ELECTROCHEMICAL ACTIVITY OF TRICLINIC LIVOPO $_{4}$ : EXPERIMENTAL CHARACTERIZATION AND THEORETICAL INVESTIGATIONS. Solid State Sci. 2008, 10 (10), 1292-1298. 
(49) Iwamoto, M.; Furukawa, H.; Matsukami, K.; Takenaka, T.; Kagawa, S. DIFFUSE REFLECTANCE INFRARED AND PHOTOLUMINESCENCE SPECTRA OF SURFACE VANADYL GROUPS. DIRECT EVIDENCE FOR CHANGE OF BOND STRENGTH AND ELECTRONIC STRUCTURE OF METAL-OXYGEN BOND UPON SUPPORTING OXIDE. J. Am. Chem. Soc. 1983,105 (11), 3719-3720.

(50) Ateba Mba, J.-M. PhD Thesis. NEW TRANSITION METAL FLUOROPHOSPHATES AS POSITIVE ELECTRODE MATERIALS FOR LI-ION BATTERIES. Univ. Bordeaux, 2013.

(51) Messinger, R. J.; Ménétrier, M.; Salager, E.; Boulineau, A.; Duttine, M.; Carlier, D.; Ateba Mba, J.-M.; Croguennec, L.; Masquelier, C.; Massiot, D.; Deschamps, M. REVEALING DEFECTS IN CRYSTALLINE LITHIUM-ION BATTERY ELECTRODES BY SOLIDSTATE NMR: APPLICATIONS TO LiVPO ${ }_{4} F$. Chem. Mater. 2015, 27 (15), 5212-5221.

(52) Bertini, I.; Luchinat, C.; Parigi, G. MAGNETIC SUSCEPTIBILITY IN PARAMAGNETIC NMR. Prog. Nucl. Magn. Reson. Spectrosc. 2002, 40 (3), 249-273.

(53) Castets, A.; Carlier, D.; Zhang, Y.; Boucher, F. A DFT-BASED ANALYSIS OF THE NMR FERMI CONTACT SHIFTS IN TAVORITE-LIKE LiMnPO ${ }_{4} \mathrm{OH}$ AND $\mathrm{MPO}_{4} \cdot \mathrm{H}_{2} \mathrm{O}(\mathrm{M}=\mathrm{Fe}, \mathrm{Mn}, \mathrm{V})$. J. Phys. Chem. C 2012, 116, 18002-18014.

(54) Castets, a; Carlier, D.; Zhang, Y.; Boucher, F.; Marx, N.; Gautier, R.; Le Fur, E.; Le Pollès, L.; Croguennec, L.; Ménétrier, M. NMR STUDY OF THE LiMnPO 4 ·OH AND MPO ${ }_{4} \cdot \mathrm{H}_{2} \mathrm{O}(\mathrm{M}$ $=$ Mn, V) HOMEOTYPIC PHASES AND DFT CALCULATIONS. Solid State Nucl. Magn. Reson. 2012, 42, 42-50. 


\section{LIST OF TABLES:}

Table 1: List of different Tavorite $\mathrm{Li}_{X} \mathrm{MPO}_{4} X$ and their average redox potential.

Table 2: Cell parameters determined from full pattern matching refinement of Laboratory $X R D$ patterns recorded for $L V P H-a, L V P H-b$ and $L V P H-c$, with the corresponding chemical analyses performed by ICP (Li, V and $P, P$ being fixed to 1) or TGA (C).

Table 3: Structural parameters obtained by combined Rietveld refinement of the structure of LVPH-a based on synchrotron XRD and Neutron Diffraction Data. Oxygen atom note by * is the bridging atom which is bound to hydrogen.

Table 4: Bond lengths (below the diagonal) and angles (above the diagonal) in coordination polyhedra of $\mathrm{V}^{3+}, \mathrm{Li}^{+}$and $\mathrm{P}^{5+}$ in $\mathrm{LiVPO}_{4} \mathrm{OH}$. The polyhedral distortion is calculated as $\Delta=\frac{1}{N} \sum_{i=0}^{N} \frac{(d i-\langle d\rangle) 2}{\langle d\rangle 2}$ with $N$ the number of bond distances considered, $d_{i}$ the distance between the atom $i$ and the central atom of the polyhedron and $(d)$ the average of the distances considered.

Table 5: Wavenumbers and assignment of the main IR vibrational bands of $\mathrm{LiVPO}_{4} \mathrm{OH}$ (W: weak). Typical bands of a $\mathrm{LiVPO}_{4} \mathrm{O}$-type environment are noted by $\nabla$.

Table 6: Electronic configuration, NMR shift $\left({ }^{7} \mathrm{Li},{ }^{1} \mathrm{H}\right.$ and $\left.{ }^{31} \mathrm{P}\right)$ and orbitals involved in the main spin transfer mechanism by delocalization of different $A M P O_{4} X$ Tavorite compounds (with $\mathrm{A}=\mathrm{Li}$ or $\mathrm{H} ; \mathrm{M}=\mathrm{V}^{4+}, \mathrm{V}^{3+}, \mathrm{Mn}^{3+}$ or $\mathrm{Fe}^{3+}$ and $\mathrm{X}=\mathrm{O}, \mathrm{F}$ or $\mathrm{OH}$ ). 
Table 1:

\begin{tabular}{|c|c|c|c|}
\hline $\begin{array}{l}\text { Redox } \\
\text { couples }\end{array}$ & $\begin{array}{l}\text { Initial / final } \\
\text { active materials }\end{array}$ & $\begin{array}{c}\text { Average } \\
\text { potential } \\
\text { (V vs Li } / \mathrm{Li})\end{array}$ & Ref. \\
\hline $\mathrm{Ti}^{3+} / \mathrm{Ti}^{2+}$ & $\mathrm{LiTi}^{\prime \prime \prime} \mathrm{PO}_{4} \mathrm{~F} / \mathrm{Li}_{2} \mathrm{Ti}^{\prime \prime} \mathrm{PO}_{4} \mathrm{~F}$ & 1.5 & 16 \\
\hline \multirow{2}{*}{$\mathrm{Ti}^{4+} / \mathrm{Ti}^{3+}$} & $\mathrm{LiTi}^{\mathrm{IV}} \mathrm{PO}_{4} \mathrm{O} / \mathrm{Li}_{2} \mathrm{Ti}^{\mathrm{III}} \mathrm{PO}_{4} \mathrm{O}$ & 1.5 & 21 \\
\hline & $\mathrm{LiTi}{ }^{I I I} \mathrm{PO}_{4} \mathrm{~F} / \mathrm{Ti}^{\mathrm{IV}} \mathrm{PO}_{4} \mathrm{~F}$ & 2.9 & 16 \\
\hline $\mathrm{V}^{3+} / \mathrm{V}^{2+}$ & $\mathrm{LiV}^{\prime \prime \prime} \mathrm{PO}_{4} \mathrm{~F} / \mathrm{Li}_{2} \mathrm{~V}^{\prime \prime} \mathrm{PO}_{4} \mathrm{~F}$ & 1.8 & 14,15 \\
\hline $\mathrm{V}^{4+}\left((\mathrm{V}=\mathrm{O})^{2+}\right) / \mathrm{V}^{3+}$ & $\mathrm{LiV}^{\prime \mathrm{V}} \mathrm{PO}_{4} \mathrm{O} / \mathrm{Li}_{2} \mathrm{~V}^{\prime \prime I} \mathrm{PO}_{4} \mathrm{O}$ & 2.3 & 15 \\
\hline $\mathrm{V}^{3+} / \mathrm{V}^{4+}$ & $\mathrm{LiV}^{\prime \prime I I} \mathrm{PO}_{4} \mathrm{~F} / \mathrm{V}^{\mathrm{IV}} \mathrm{PO}_{4} \mathrm{~F}$ & 4.23 & 14,15 \\
\hline $\mathrm{V}^{5+} / \mathrm{V}^{4+}\left((\mathrm{V}=\mathrm{O})^{2+}\right)$ & $\mathrm{LiV}^{\mathrm{IV}} \mathrm{PO}_{4} \mathrm{O} / \mathrm{V}^{\mathrm{V}} \mathrm{PO}_{4} \mathrm{O}$ & 3.95 & 15 \\
\hline $\mathrm{V}^{5+} / \mathrm{V}^{3+}$ & $\mathrm{HV}^{\prime \prime \prime} \mathrm{PO}_{4} \mathrm{OH} / \mathrm{V}^{\mathrm{V}} \mathrm{PO}_{4} \mathrm{O}$ & 4.0 & 18 \\
\hline $\mathrm{Mn}^{4+} / \mathrm{Mn}^{3+}$ & $\mathrm{LiMn}^{\prime \prime \prime} \mathrm{PO}_{4} \mathrm{OH} / \mathrm{Mn}^{\mathrm{IV}} \mathrm{PO}_{4} \mathrm{OH}$ & 3.25 & 19 \\
\hline \multirow{3}{*}{$\mathrm{Fe}^{3+} / \mathrm{Fe}^{2+}$} & $\mathrm{LiFe}^{\prime \prime \prime} \mathrm{PO}_{4} \mathrm{~F} / \mathrm{Li}_{2} \mathrm{Fe}^{\prime \prime} \mathrm{PO}_{4} \mathrm{~F}$ & 2.9 & 16 \\
\hline & $\mathrm{LiFe}{ }^{\prime \prime \prime} \mathrm{PO}_{4} \mathrm{OH} / \mathrm{Li}_{2} \mathrm{Fe}{ }^{\mid "} \mathrm{PO}_{4} \mathrm{OH}$ & 2.6 & 12 \\
\hline & $\mathrm{HFe}^{\text {III }} \mathrm{PO}_{4} \mathrm{OH} / \mathrm{LiHFe}^{\prime \prime} \mathrm{PO}_{4} \mathrm{OH}$ & 3.2 & 13 \\
\hline
\end{tabular}




\begin{tabular}{|c|c|c|c|}
\hline & LVPH-a & LVPH-b & LVPH-c \\
\hline \multicolumn{4}{|c|}{ Cell parameters, $\boldsymbol{P}-1$} \\
\hline$a(\AA)=$ & $5.1341(2)$ & $5.1369(5)$ & $5.1320(5)$ \\
\hline$b(\AA)=$ & $5.3342(3)$ & $5.3387(6)$ & $5.3286(6)$ \\
\hline$c(\AA)=$ & $7.2833(2)$ & $7.2814(5)$ & $7.2902(5)$ \\
\hline$\alpha\left({ }^{\circ}\right)=$ & $106.557(2)$ & $106.538(5)$ & $106.584(5)$ \\
\hline$\beta\left(^{\circ}\right)=$ & $109.216(3)$ & $109.201(6)$ & $109.206(6)$ \\
\hline$\gamma\left({ }^{\circ}\right)=$ & $97.350(2)$ & $97.310(6)$ & $97.335(5)$ \\
\hline$V\left(\AA^{3}\right)=$ & $175.04(1)$ & $175.32(3)$ & $174.95(2)$ \\
\hline \multicolumn{4}{|c|}{ Chemical analyses (Molar ratio) } \\
\hline $\mathrm{Li} / \mathrm{V} / \mathrm{P}=$ & $0.94 / 0.96 / 1$ & $0.95 / 0.98 / 1$ & $0.97 / 1.07 / 1$ \\
\hline $\mathrm{C} w \mathrm{t} \%=$ & / & 14.9 & / \\
\hline
\end{tabular}

Table 2: 
Table 3:

\begin{tabular}{|c|c|c|c|c|c|c|c|}
\hline \multicolumn{8}{|c|}{$\mathrm{LiVPO}_{4} \mathrm{OH}$} \\
\hline \multicolumn{2}{|c|}{$\begin{aligned} \text { SG } & : P-1 \\
Z & =2\end{aligned}$} & \multicolumn{2}{|c|}{$\begin{array}{c}a=5.1335(1) \AA \\
b=5.3334(1) \AA \\
c=7.2824(2) \AA \\
V=174.968(6) \AA^{3}\end{array}$} & \multicolumn{2}{|c|}{$\begin{array}{c}\alpha=106.557(2)^{\circ} \\
\beta=109.217(2)^{\circ} \\
\gamma=97.352(2)^{\circ} \\
V / Z=87.484(6) \AA^{3}\end{array}$} & $\begin{array}{c}\text { synchrotron: } \\
\text { neutrons: }\end{array}$ & \multirow{2}{*}{$\begin{array}{c}\chi^{2}=22.9 \% \\
\mathrm{R}_{\text {bragg }}=3.73 \% \\
\chi^{2}=1.68 \% \\
\mathrm{R}_{\text {bragg }}=6.56 \% \\
\text { BVS }\end{array}$} \\
\hline atoms & $\begin{array}{l}\text { Wickoff } \\
\text { position }\end{array}$ & $x$ & $y$ & $z$ & occupancy & $B$ iso & \\
\hline $\mathrm{V}(1)$ & $1 a$ & 0 & 0 & 0 & 1 & $0.54(8)$ & $2.93(3)$ \\
\hline$V(2)$ & $1 b$ & 0 & 0 & $1 / 2$ & 1 & $0.36(7)$ & $3.00(2)$ \\
\hline$P(1)$ & $2 i$ & $0.3234(6)$ & $0.6388(6)$ & $0.2680(5)$ & 1 & $0.16(7)$ & $5.01(6)$ \\
\hline$O(1)$ & $2 i$ & $0.629(2)$ & $0.751(2)$ & $0.429(1)$ & 1 & $0.20(5)$ & $2.09(3)$ \\
\hline$O(2)$ & $2 i$ & $0.111(2)$ & $0.661(2)$ & $0.377(1)$ & 1 & $0.12(5)$ & $2.03(4)$ \\
\hline$O(3)$ & $2 i$ & $0.308(2)$ & $0.340(2)$ & $0.159(1)$ & 1 & $0.31(5)$ & $2.07(3)$ \\
\hline $\mathrm{O}(4)$ & $2 i$ & $0.267(2)$ & $0.790(2)$ & $0.117(1)$ & 1 & $0.43(6)$ & $2.04(4)$ \\
\hline$O(5)^{*}$ & $2 i$ & $0.155(2)$ & $0.947(2)$ & $0.772(1)$ & 1 & $0.16(5)$ & $1.87(3)$ \\
\hline$H(1)$ & $2 i$ & $0.351(9)$ & $0.063(9)$ & $0.347(7)$ & 1 & $8.5(3)$ & $1.14(9)$ \\
\hline \multirow[t]{2}{*}{$\mathrm{Li}(1)$} & $2 i$ & $0.260(6)$ & $0.605(6)$ & $0.686(5)$ & 1 & $3.7(7)$ & $0.99(4)$ \\
\hline & & $B_{11}$ & $B_{22}$ & $\mathrm{~B}_{33}$ & $\mathrm{~B}_{12}$ & $\mathrm{~B}_{13}$ & $\mathrm{~B}_{23}$ \\
\hline \multicolumn{2}{|c|}{$\mathrm{B}_{\text {anisotropic }}$ of Lithium } & 0.098 & 0.036 & 0.076 & 0.004 & -0.039 & -0.020 \\
\hline
\end{tabular}


Table 4:

\begin{tabular}{|c|c|c|c|c|c|c|c|c|}
\hline \multicolumn{9}{|c|}{$\mathrm{V}(1) \mathrm{O}_{4}(\mathrm{OH})_{2}$} \\
\hline$O(3)$ & $2.01(1)$ & 180 & $89.6(3)$ & $90.4(3)$ & $86.6(3)$ & $93.4(3)$ & $66.4(3)$ & 113.6() \\
\hline$O\left(3^{\prime}\right)$ & $4.02(1)$ & $2.01(1)$ & $90.4(3)$ & $89.6(3)$ & $93.4(3)$ & $86.6(3)$ & $113.6(3)$ & $66.4(3)$ \\
\hline$O(4)$ & $2.82(1)$ & $2.84(1)$ & $1.99(1)$ & 180 & $86.1(3)$ & $93.9(3)$ & $76.7(3)$ & $103.3(3)$ \\
\hline$O\left(4^{\prime}\right)$ & $2.84(1)$ & $2.82(1)$ & $3.99(1)$ & $1.99(1)$ & $93.9(3)$ & $86.1(3)$ & $103.3(3)$ & $76.7(3)$ \\
\hline$O(5)$ & $2.77(1)$ & $2.95(1)$ & $2.75(1)$ & $2.95(1)$ & $2.04(1)$ & 180 & $22.6(3)$ & $157.4(3)$ \\
\hline$O\left(5^{\prime}\right)$ & $2.95(1)$ & $2.77(1)$ & $2.95(1)$ & $2.75(1)$ & $4.08(1)$ & $2.04(1)$ & $157.4(3)$ & $22.6(3)$ \\
\hline$H(1)$ & $2.57(3)$ & $3.86(3)$ & $2.88(3)$ & $3.62(3)$ & $1.06(3)$ & $4.54(3)$ & $2.59(6)$ & 180 \\
\hline$H\left(1^{\prime}\right)$ & $3.86(3)$ & $2.57(3)$ & $3.62(3)$ & $2.88(3)$ & $4.54(3)$ & $1.06(3)$ & $5.18(5)$ & $2.59(6)$ \\
\hline \multicolumn{9}{|c|}{$\Delta=1.35 \times 10^{-5}$} \\
\hline \multicolumn{9}{|c|}{$\mathrm{V}(2) \mathrm{O}_{4}(\mathrm{OH})_{2}$} \\
\hline & $O(1)$ & $O\left(1^{\prime}\right)$ & $O(2)$ & $O\left(2^{\prime}\right)$ & $O(5)$ & $O\left(5^{\prime}\right)$ & $H(1)$ & $H\left(1^{\prime}\right)$ \\
\hline$O(1)$ & $1.99(1)$ & 180 & $95.8(3)$ & $84.2(3)$ & $89.8(3)$ & $90.2(3)$ & $66.1(4)$ & $113.9(4)$ \\
\hline$O\left(1^{\prime}\right)$ & $3.98(1)$ & $1.99(1)$ & $84.2(3)$ & $95.8(3)$ & $90.2(3)$ & $89.8(3)$ & $113.9(4)$ & $66.1(4)$ \\
\hline$O(2)$ & $2.98(1)$ & $2.69(2)$ & $2.02(1)$ & 180 & $86.5(3)$ & $93.5(3)$ & $86.3(4)$ & $93.8(4)$ \\
\hline$O\left(2^{\prime}\right)$ & $2.69(2)$ & $2.98(1)$ & $4.04(1)$ & $2.02(1)$ & $93.5(3)$ & $86.5(3)$ & $93.8(4)$ & $86.3(4)$ \\
\hline$O(5)$ & $2.82(1)$ & $2.82(1)$ & $2.75(1)$ & $2.92(1)$ & $1.99(1)$ & 180 & $23.9(4)$ & $156.0(4)$ \\
\hline$O\left(5^{\prime}\right)$ & $2.82(1)$ & $2.82(1)$ & $2.92(1)$ & $2.75(1)$ & $3.99(1)$ & $1.99(1)$ & $156.0(4)$ & $23.9(4)$ \\
\hline$H(1)$ & $2.48(3)$ & $3.77(3)$ & $3.10(3)$ & $3.31(3)$ & $1.06(3)$ & $4.41(9)$ & $2.54(6)$ & 180 \\
\hline$H\left(1^{\prime}\right)$ & $3.77(3)$ & $2.48(3)$ & $3.31(3)$ & $3.10(3)$ & $4.41(9)$ & $1.06(3)$ & $4.99(6)$ & $2.54(6)$ \\
\hline \multicolumn{9}{|c|}{$\Delta=2.73 \times 10^{-5}$} \\
\hline \multicolumn{9}{|c|}{$\mathrm{PO}_{4}$} \\
\hline & \multicolumn{2}{|c|}{$O(1)$} & \multicolumn{2}{|c|}{$O(2)$} & \multicolumn{2}{|c|}{$O(3)$} & \multicolumn{2}{|c|}{$O(4)$} \\
\hline$O(1)$ & \multicolumn{2}{|c|}{$1.54(1)$} & \multicolumn{2}{|c|}{$109.5(6)$} & \multicolumn{2}{|c|}{$102.8(5)$} & \multicolumn{2}{|c|}{$110.4(5)$} \\
\hline$O(2)$ & \multicolumn{2}{|c|}{$2.53(2)$} & \multicolumn{2}{|c|}{$1.56(1)$} & \multicolumn{2}{|c|}{$110.5(5)$} & \multicolumn{2}{|c|}{$111.4(5)$} \\
\hline$O(3)$ & \multicolumn{2}{|c|}{$2.42(1)$} & \multicolumn{2}{|c|}{$2.55(1)$} & \multicolumn{2}{|c|}{$1.55(1)$} & \multicolumn{2}{|c|}{$111.9(6)$} \\
\hline$O(4)$ & \multicolumn{2}{|c|}{$2.52(1)$} & & & \multicolumn{2}{|c|}{$2.55(1)$} & \multicolumn{2}{|c|}{$1.53(1)$} \\
\hline \multicolumn{9}{|c|}{$\Delta=3.65 \times 10^{-5}$} \\
\hline \multicolumn{9}{|c|}{$\mathrm{LiO}_{4}(\mathrm{OH})$} \\
\hline & & $O(1)$ & $O(2)$ & $O\left(2^{\prime}\right)$ & $O(3)$ & $O(5)$ & $H(1)$ & \\
\hline$O(1)$ & & $2.06(3)$ & $91.7(9)$ & $82.9(9)$ & $71.8(9)$ & $171.3(9)$ & $148.6(9)$ & \\
\hline$O(2)$ & & $3.12(1)$ & $2.28(4)$ & $94.0(9)$ & $140.6(9)$ & $80.4(9)$ & $87.2(9)$ & \\
\hline$O\left(2^{\prime}\right)$ & & $2.69(2)$ & $3.13(1)$ & $2.00(4)$ & $115.9(9)$ & $101.3(9)$ & $128.5(9)$ & \\
\hline$O(3)$ & & $2.42(1)$ & $3.67(1)$ & $3.82(1)$ & $2.06(4)$ & $108.2(9)$ & $80.5(9)$ & \\
\hline$O(5)$ & & $4.02(1)$ & $2.75(1)$ & $3.07(1)$ & $3.26(1)$ & $1.97(4)$ & $28.3(6)$ & \\
\hline$H(1)$ & & $4.13(4)$ & $3.11(4)$ & $3.81(4)$ & $2.77(4)$ & $1.06(3)$ & $2.23(4)$ & \\
\hline & & & & $=1.79 \times 1$ & & & & \\
\hline
\end{tabular}


Table 5:

\begin{tabular}{ccccc}
\multicolumn{5}{c}{ wavenumber $\left(\mathrm{cm}^{-1}\right)$} \\
LVPH-a & LVPH-b & LVPH-c & assignment & ref \\
\hline 3305 & 3300 & 3303 & $v_{\mathrm{O}-\mathrm{H}}$ & 13,47 \\
\hline$/$ & $1167(\mathrm{w})$ & $1167(\mathrm{w})$ & $v_{\mathrm{PO} 4} \nabla$ & 35,48 \\
1087 & 1082 & 1083 & $v_{\mathrm{PO} 4}$ & $27,35,48$ \\
1042 & 1034 & 1048 & $v_{\mathrm{PO} 4}$ & $27,35,48$ \\
988 & 988 & 989 & $v_{\mathrm{PO} 4}$ & $27,35,48$ \\
$/$ & $950(\mathrm{w})$ & $949(\mathrm{w})$ & $v_{\mathrm{PO} 4} \nabla$ & 35,47 \\
\hline $891(\mathrm{w})$ & 891 & 902 & $v_{\mathrm{V}=\mathrm{O}} \nabla$ & $35,48,49$ \\
829 & 829 & 829 & $v_{\mathrm{V}-\mathrm{O}}$ & 13 \\
\hline
\end{tabular}


Table 6:

\begin{tabular}{|c|c|c|c|c|}
\hline${ }^{7} \mathrm{Li}$ & $\begin{array}{c}\text { electronic } \\
\text { configuration }\end{array}$ & $\begin{array}{l}\text { isotropic peak } \\
\text { position (ppm) }\end{array}$ & $\begin{array}{l}\text { spin transfer } \\
\text { mechanism }\end{array}$ & ref \\
\hline $\mathrm{LiV}^{4+} \mathrm{PO}_{4} \mathrm{O}$ & $t_{2 g^{1}} e^{0}{ }^{0}$ & 79 & $t_{2 g}$ & 50 \\
\hline $\mathrm{LiV}^{3+} \mathrm{PO}_{4} \mathrm{~F}$ & $t_{2 g}{ }^{2} e g^{0}$ & 117 & $t_{2 g}$ & 50,51 \\
\hline $\mathrm{LiV}^{3+} \mathrm{PO}_{4} \mathrm{OH}$ & $t_{2 g}{ }^{2} e^{0}$ & 149 & $t_{2 g}$ & this work \\
\hline $\mathrm{LiMn}^{3+} \mathrm{PO}_{4} \mathrm{OH}$ & $t_{2 g}{ }^{3} e^{1}$ & 340 & $t_{2 g}$ & 53,54 \\
\hline $\mathrm{LiFe}^{3+} \mathrm{PO}_{4} \mathrm{OH}$ & $t_{2 g^{3}} e^{2}$ & 214 & $t_{2 g}+e_{g}$ & 53 \\
\hline${ }^{1} \mathrm{H}$ & $\begin{array}{c}\text { electronic } \\
\text { configuration }\end{array}$ & $\begin{array}{c}\text { isotropic peak } \\
\text { position }\end{array}$ & $\begin{array}{c}\text { spin transfer } \\
\text { mechanism }\end{array}$ & Ref \\
\hline $\mathrm{LiV}^{3+} \mathrm{PO}_{4} \mathrm{OH}$ & $t_{2 g^{2}} e^{0}$ & 672 & $t_{2 g}$ & this work \\
\hline $\mathrm{LiMn}^{3+} \mathrm{PO}_{4} \mathrm{OH}$ & $t_{2 g}{ }^{3} e^{1}$ & 815 & $t_{2 g}$ & 5354 \\
\hline $\mathrm{LiFe}^{3+} \mathrm{PO}_{4} \mathrm{OH}$ & $t_{2 g^{3}} e^{2}$ & 162 & $t_{2 g}$ & 53 \\
\hline${ }^{31} \mathrm{p}$ & $\begin{array}{c}\text { electronic } \\
\text { configuration }\end{array}$ & $\begin{array}{c}\text { isotropic peak } \\
\text { position }\end{array}$ & $\begin{array}{c}\text { spin transfer } \\
\text { mechanism }\end{array}$ & Ref \\
\hline $\mathrm{LiV}^{4+} \mathrm{PO}_{4} \mathrm{O}$ & $t_{2 g}{ }^{1} e^{0}$ & $1418+1593$ & $t_{2 g}$ & 50 \\
\hline $\mathrm{LiV}^{3+} \mathrm{PO}_{4} \mathrm{~F}$ & $t_{2 g}^{2} e^{0}$ & 3998 & $t_{2 g}$ & 50 \\
\hline $\mathrm{LiV}^{3+} \mathrm{PO}_{4} \mathrm{OH}$ & $t_{2 g}{ }^{2} e g^{0}$ & 4300 & $t_{2 g}$ & this work \\
\hline $\mathrm{LiMn}^{3+} \mathrm{PO}_{4} \mathrm{OH}$ & $t_{2 g}{ }^{3} e g^{1}$ & 8483 & $t_{2 g}$ & 53,54 \\
\hline $\mathrm{LiFe}^{3+} \mathrm{PO}_{4} \mathrm{OH}$ & $t_{2 g}{ }^{3} e g^{2}$ & 7498 & $t_{2 g}+e_{g}$ & 53 \\
\hline
\end{tabular}




\section{LIST OF FIGURES:}

Figure 1: XRD patterns of $3 \mathrm{LiVPO}_{4} \mathrm{OH}$ powders (LVPH-a in red, $\mathrm{LVPH}-b$ in blue, LVPH-c in orange) and other vanadium based compounds with Tavorite structure ( $\mathrm{HVPO}{ }_{4} \mathrm{OH}, \mathrm{LiVPO}_{4} \mathrm{~F}$ and $\mathrm{LiVPO}_{4} \mathrm{O}$ plotted as black lines). The theoretical Bragg positions are indicated as black ticks.

Figure 2: SEM images of $L V P H-a, L V P H-b$ and $L V P H-c$.

Figure 3: Rietveld refinement of the structure of $\mathrm{LVPH}-\mathrm{a}$ based on combined refinement of Synchrotron X-rays (a) and Neutrons (b) diffraction patterns. The observed intensities are plotted as red points, the theoretical Bragg positions are plotted as blue marks, calculated intensities and the difference between observed and calculated intensities are plotted as black lines. Impurities are spotted by $\nabla$ or *.

Figure 4: (a) Structure of $\mathrm{LVPH}$-a along the [001] direction: $\mathrm{VO}_{4}(\mathrm{OH})_{2}$ octahedra in blue, $\mathrm{PO}_{4}$ tetrahedra in grey and anisotropic Debye-Waller factor of lithium in purple, dot lines represent the hydrogen bond $\mathrm{O}(4){ }^{\cdots} \mathrm{H}$; (b) Lithium diffusion pathway calculated thanks to Bond Valence Energy Landscape (with an energy of $1.6 \mathrm{eV}$ ).

Figure 5: Diffuse reflectance infrared spectra of $\angle V P H-a$ (red line), $L V P H-b$ (blue line), $L V P H-c$ (orange line) and $\mathrm{VPO}_{4} \cdot \mathrm{H}_{2} \mathrm{O}$ (purple line, in inset). Typical bands of a LiVPO${ }_{4} \mathrm{O}$-type environment are noted by $\mathrm{D}$.

Figure 6: ${ }^{7} \mathrm{Li}(a),{ }^{1} \mathrm{H}(b)$ and ${ }^{31} \mathrm{P}(\mathrm{c}) \mathrm{MAS} N \mathrm{NR}$ spectra of $\mathrm{LVPH}$ samples $\mathrm{LVPH}-\mathrm{a}(\mathrm{red}), \mathrm{LVPH}-b$ (blue), LVPH-c (purple). Isotropic signals are noted by \#, their spinning side bands by * and additional peaks by lor by $\nabla$ (see text).

Figure 7: GITT (blue line) curves of LVPH-b cycled between 3.0 and 4.4V (a) and 3.0 and $1.2 \mathrm{~V}$ (b) vs. $\mathrm{Li}^{+} / \mathrm{Li}$. Dot lines represent the galvanostatic cycling of $\mathrm{LVPH}-b$ used to obtain the ex-situ materials whose XRD patterns are shown in figure 8.

Figure 8: EX-situ XRD patterns (blue point) of pristine LVPH-b (1), the end-of-(dis)charge materials obtained after cycling in the voltage regions 4.5-3.0 V (2 and 3) and 3.0-1.2 V (4 and 5) vs. Li ${ }^{+} / L i$. Theoretical Bragg positions (black ticks) and patterns calculated by the Rietveld method. *A LiVPO ${ }_{4} \mathrm{OH}$-type phase was added as a secondary contribution. 
Figure 1:

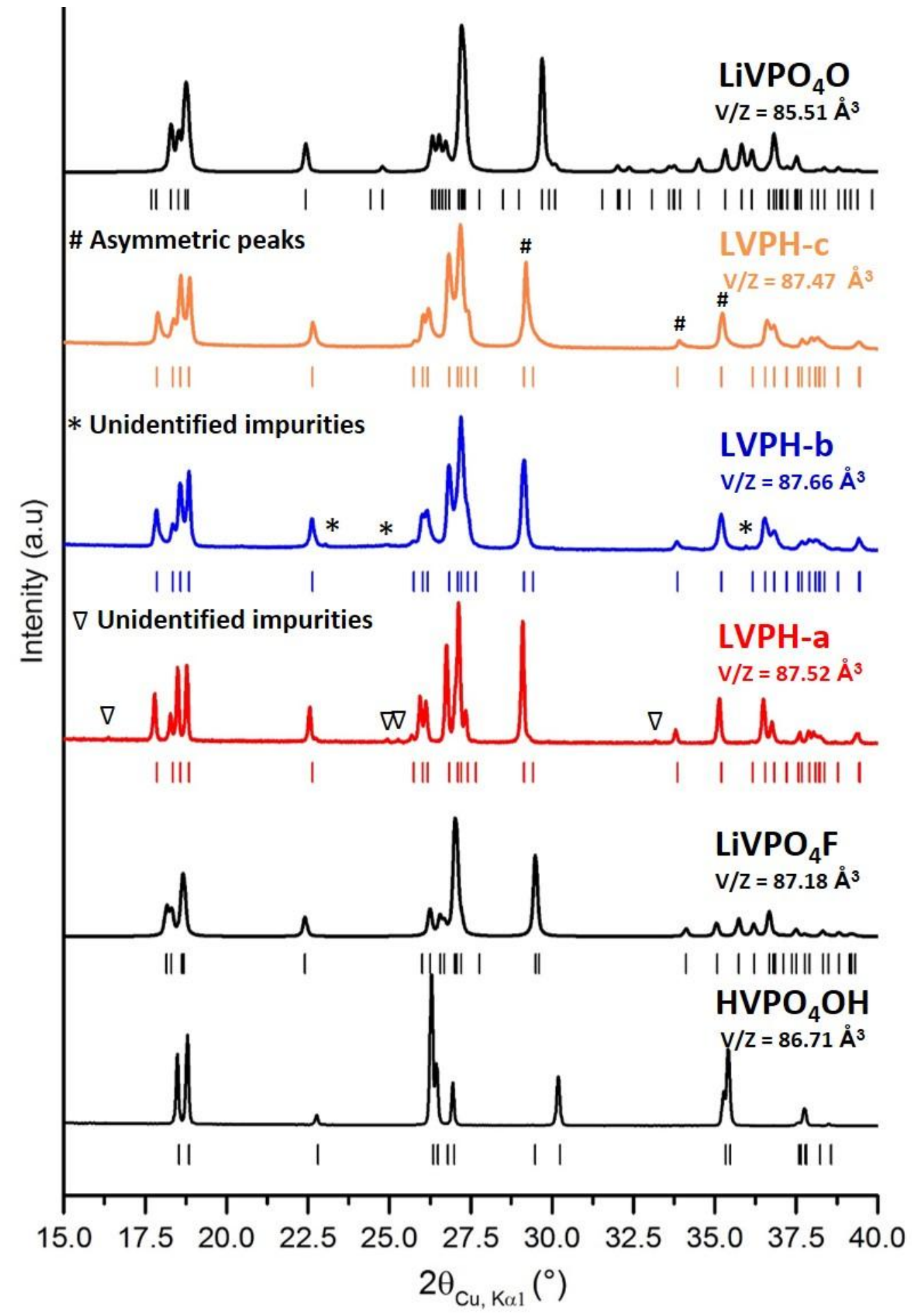


Figure 2:
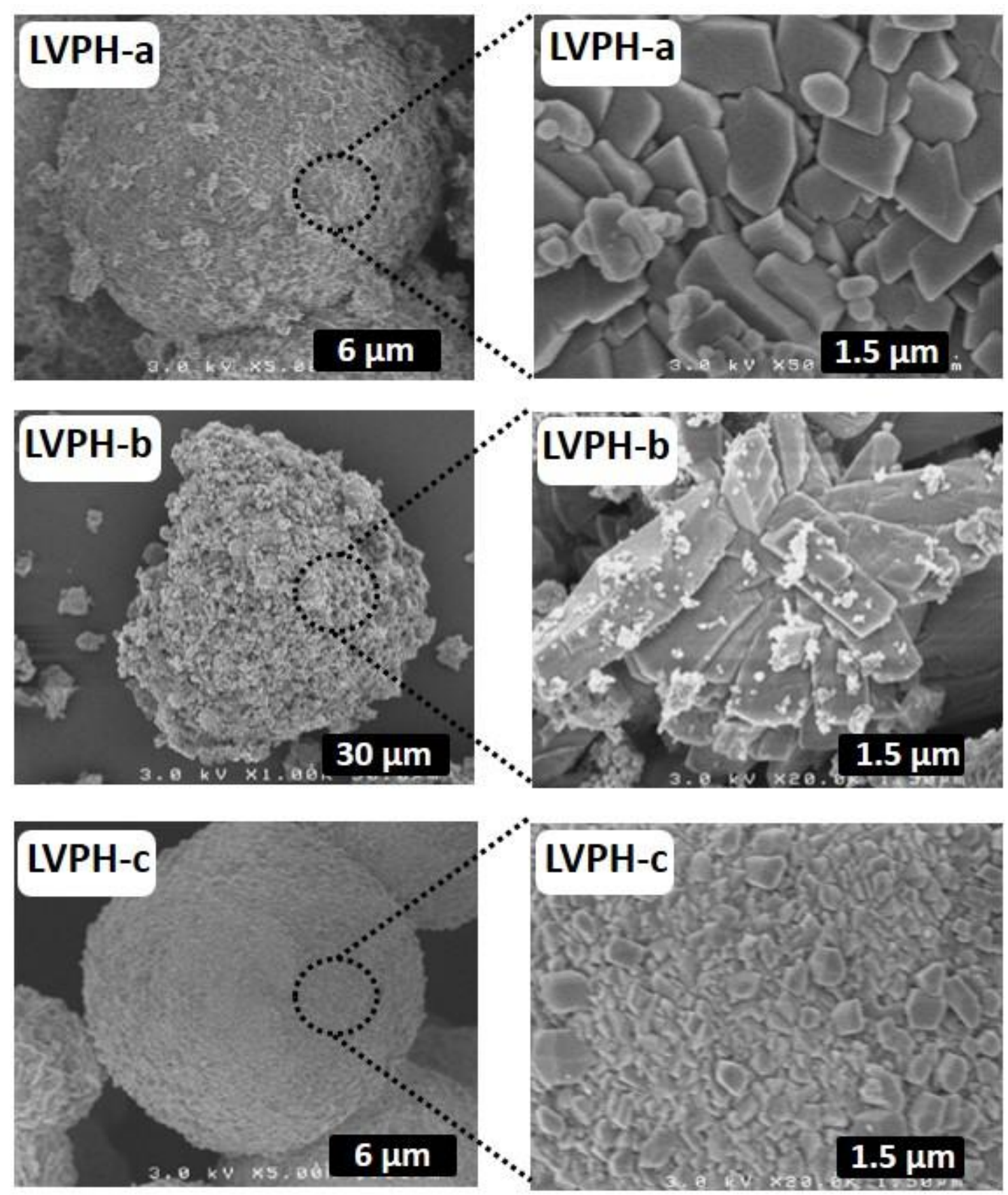
Figure 3:
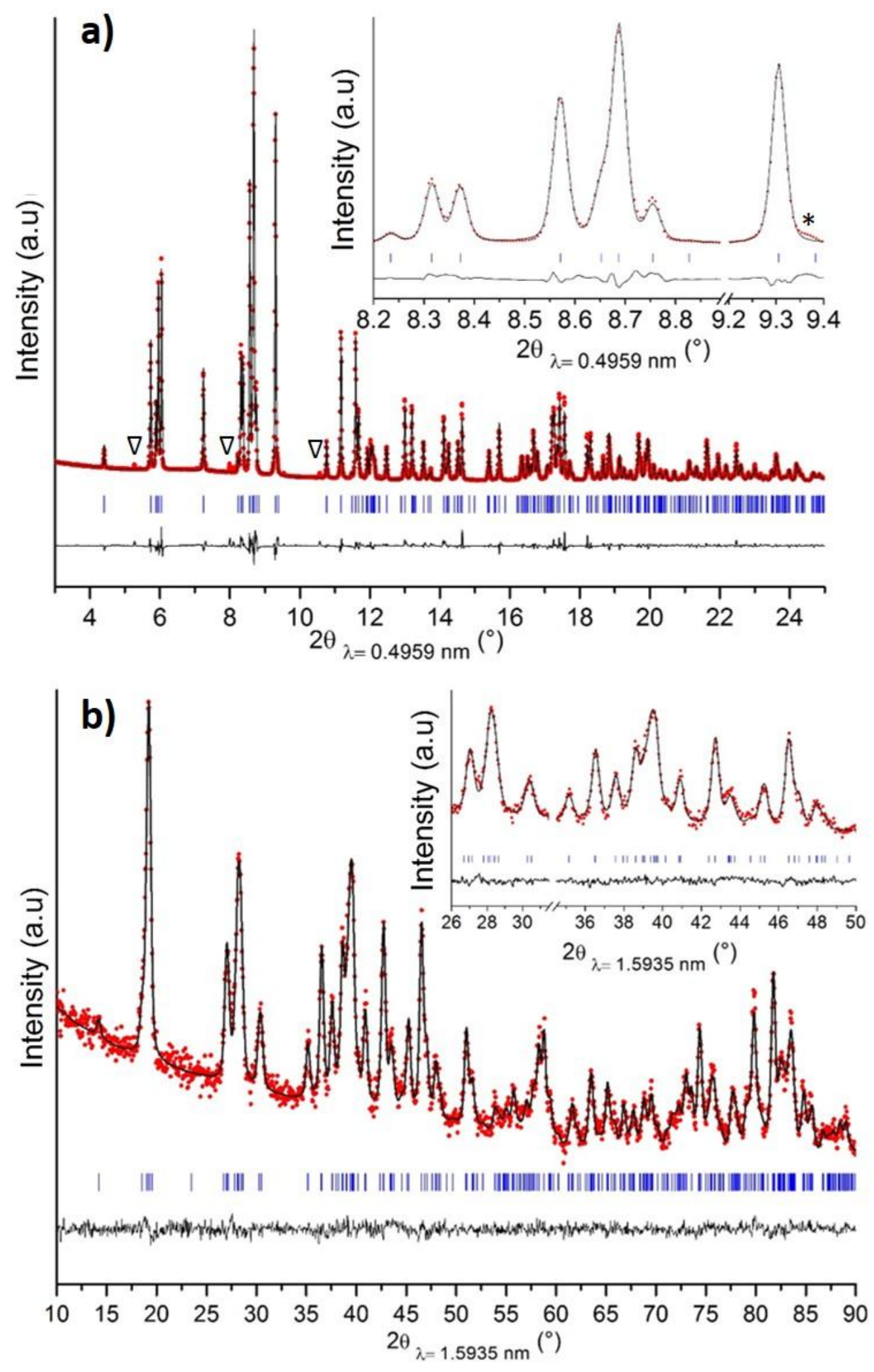
Figure 4:

a)

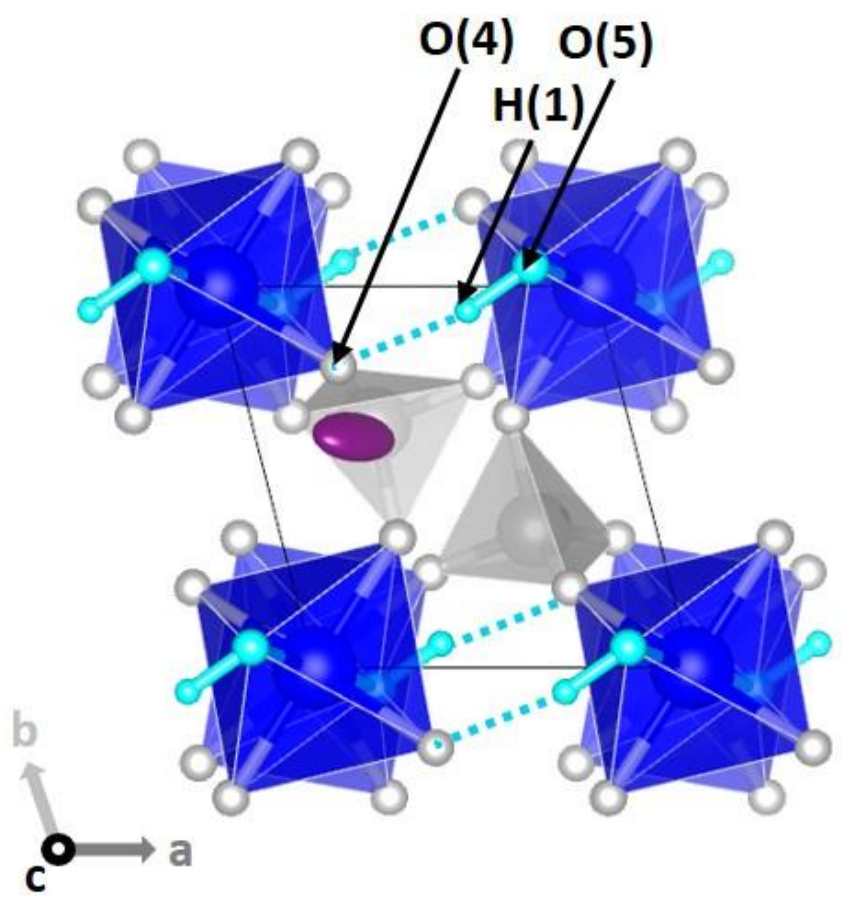

b)

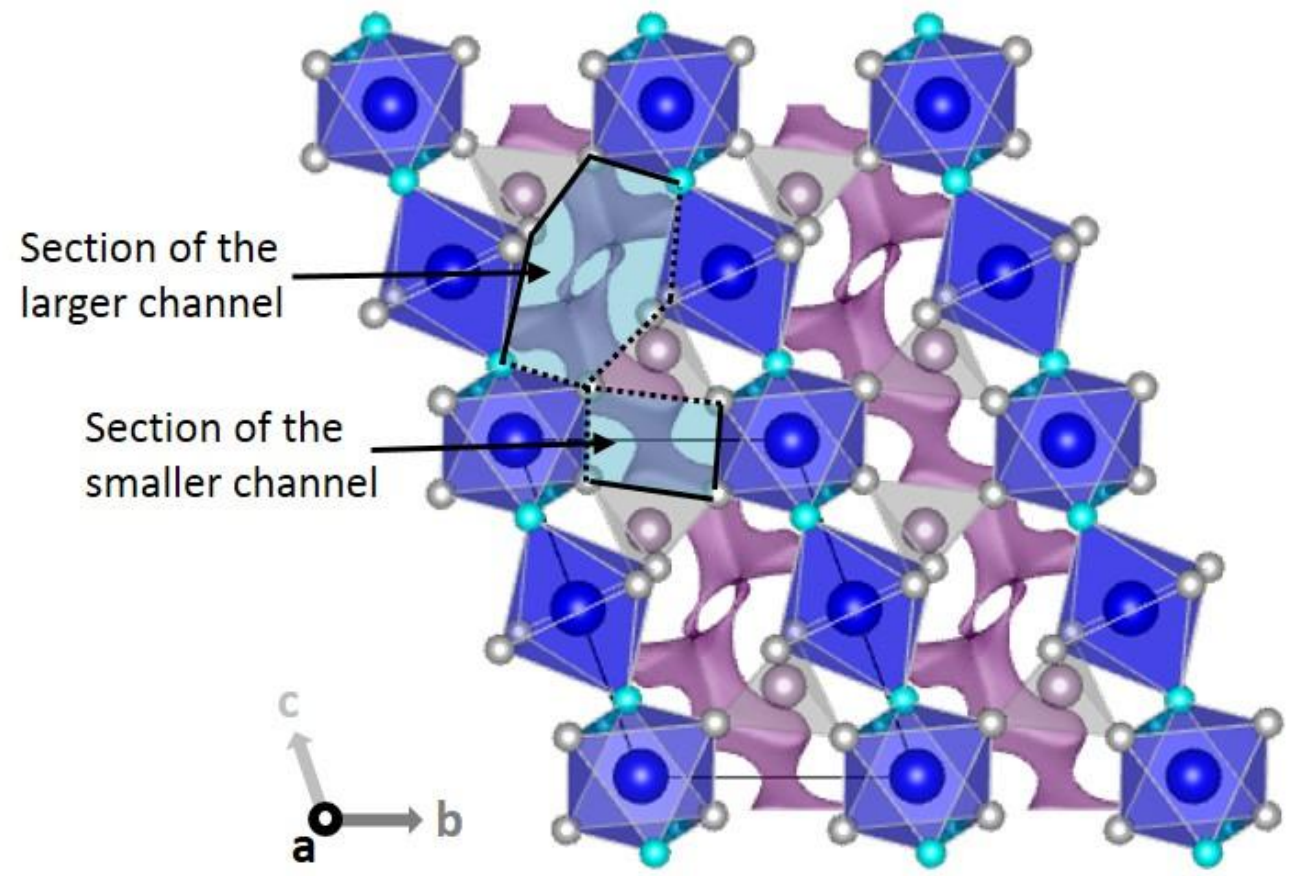


Figure 5:

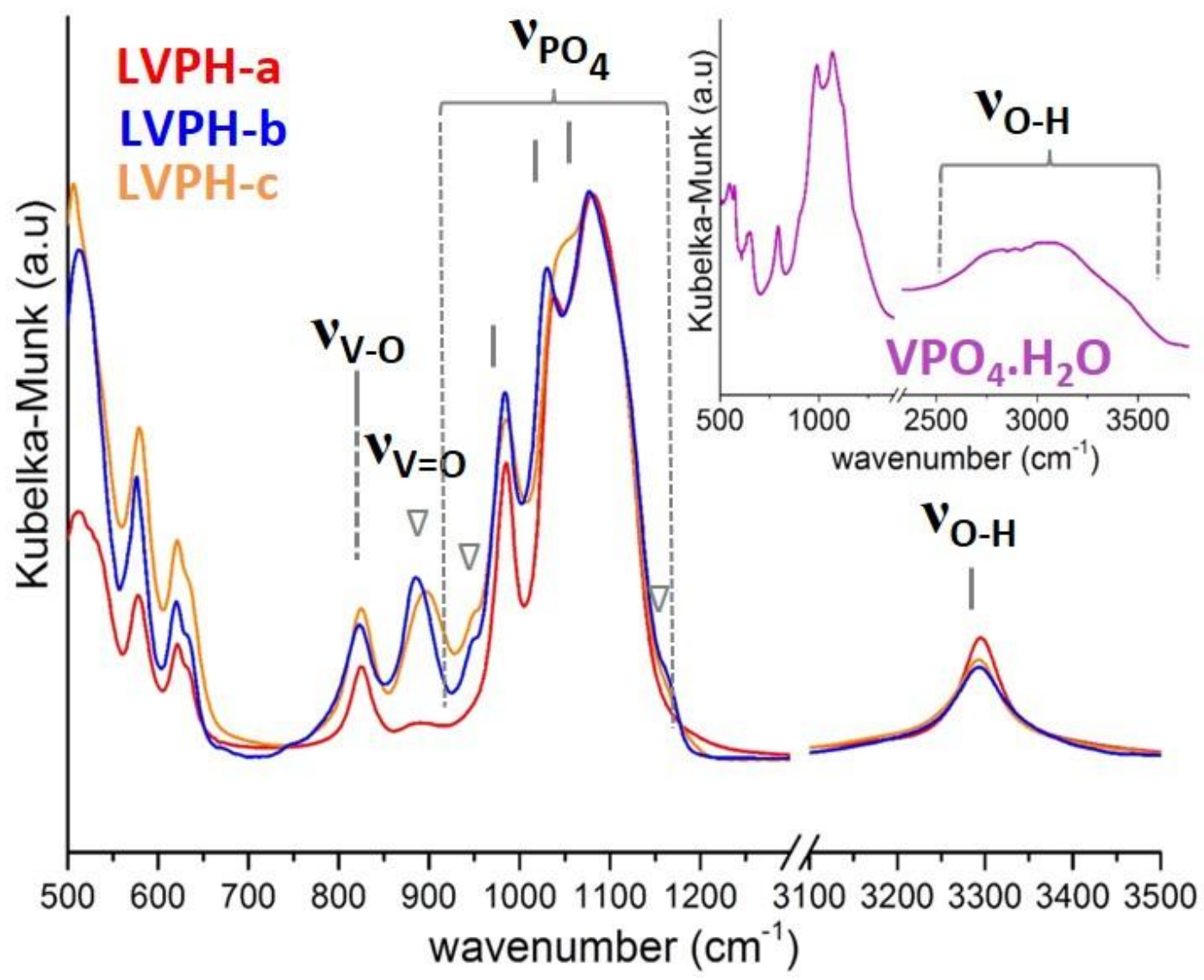


Figure 6:
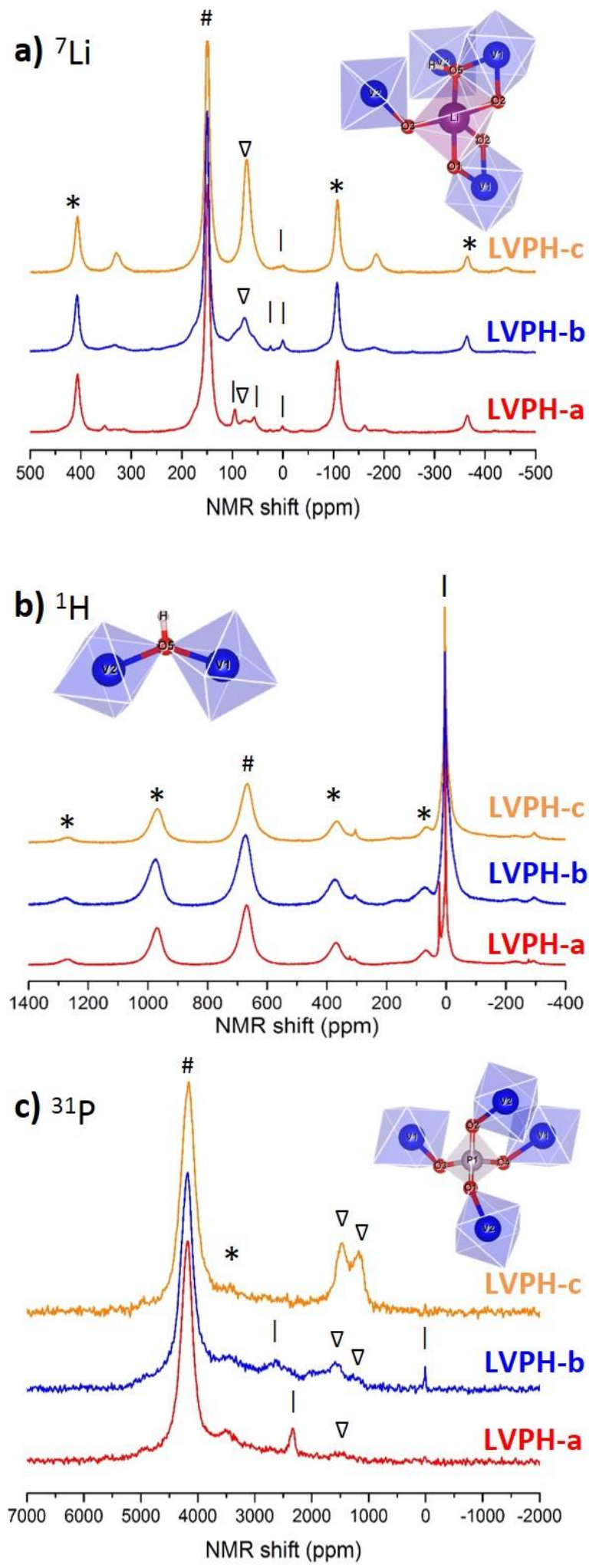
Figure 7:
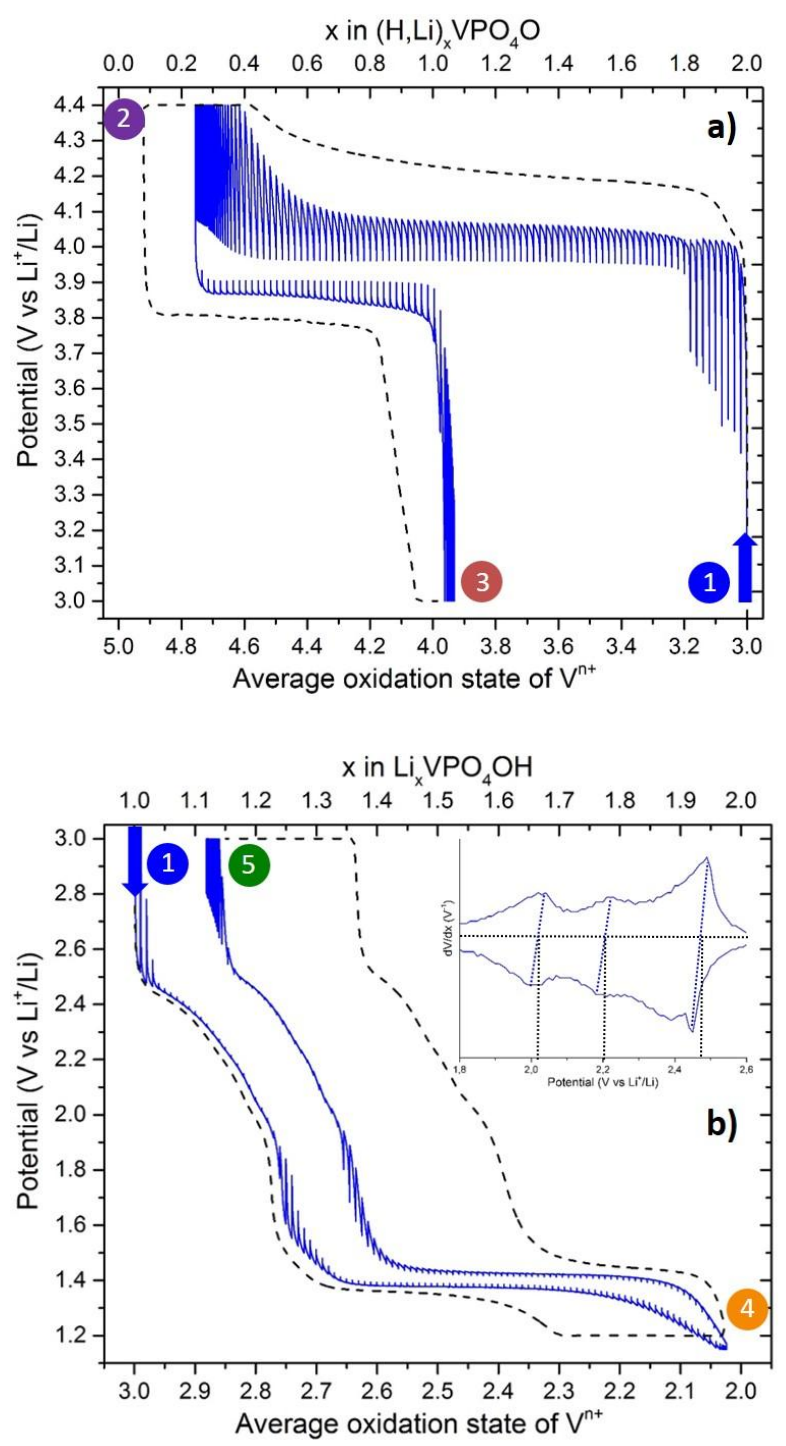
Figure 8:

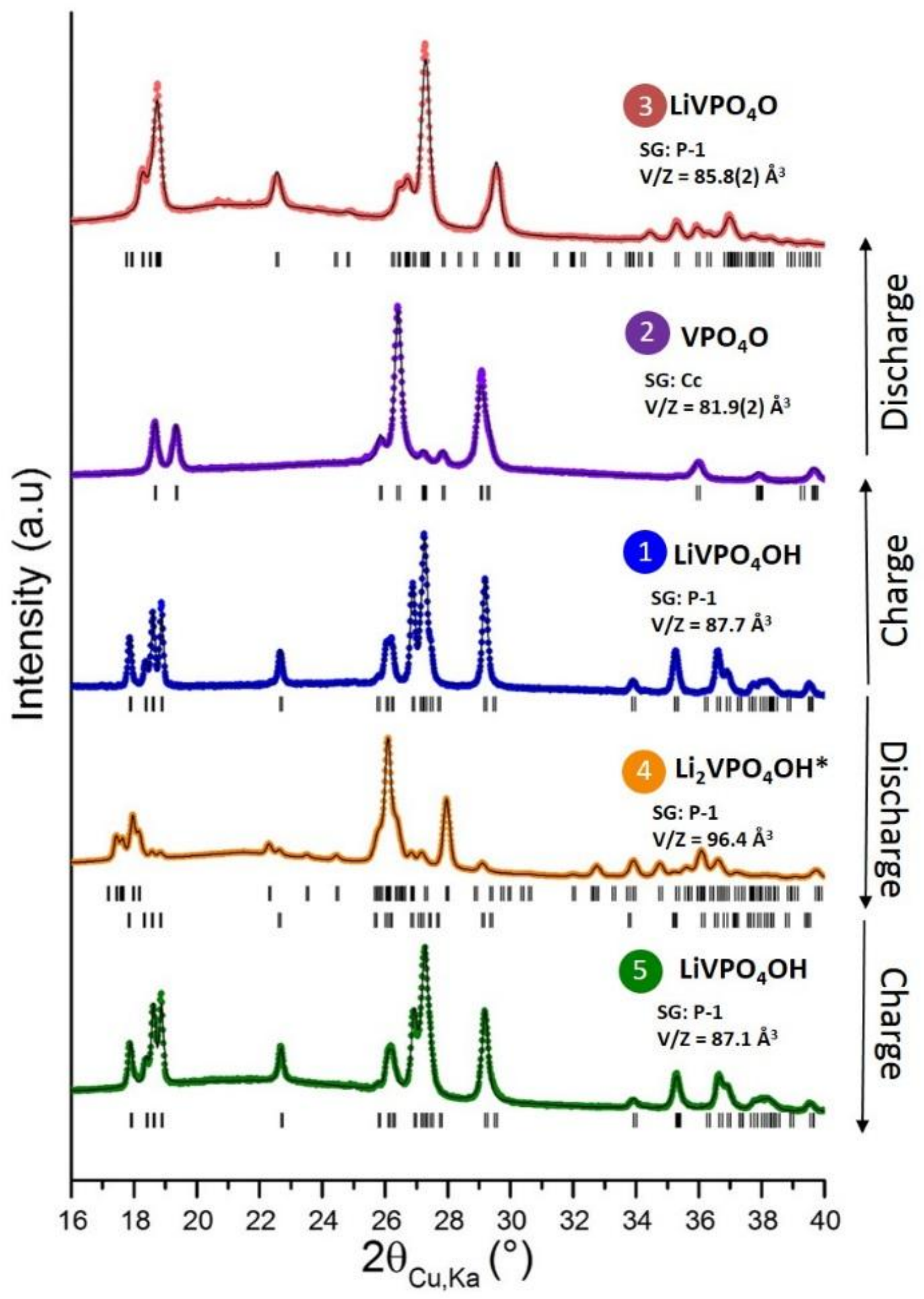




\section{Supplementary information}

\section{Structural and Electrochemical Studies of a New Tavorite Composition: $\mathrm{LiVPO}_{4} \mathrm{OH}$}

\footnotetext{
Edouard Boivin ${ }^{\mathrm{a}, \mathrm{b}, \mathrm{g}}$, Jean-Noël Chotard ${ }^{\mathrm{b}, \mathrm{g}, \mathrm{h}}$, Michel Ménétrier ${ }^{\mathrm{a}, \mathrm{g}}$, Lydie Bourgeois c,d , Tahya Bamine ${ }^{a, g}$, Dany Carlier ${ }^{a}$ g, François Fauth ${ }^{e}$, Emmanuelle Suard ${ }^{f}$, Christian Masquelier ${ }^{b, g, h}$ and Laurence Croguennec ${ }^{a, g, h,+}$

${ }^{a}$ CNRS, Univ. Bordeaux, Bordeaux INP, ICMCB UPR 9048, F-33600 Pessac, France.

${ }^{b}$ Laboratoire de Réactivité et de Chimie des Solides, CNRS-UMR\#7314, Université de Picardie Jules Verne, F-80039 Amiens Cedex 1, France.

'Université de Bordeaux, ISM, Groupe de Spectroscopie Moléculaire, F-33405 Talence, France.

${ }^{d}$ Bordeaux INP, ISM, CNRS, UMR 5255, F-33405, Talence, France.

${ }^{e}$ CELLS - ALBA synchrotron, E-08290 Cerdanyola del Vallès, Barcelona, Spain.

${ }^{f}$ Institut Laue-Langevin, 71 Avenue des Martyrs, F-38000 Grenoble, France.

${ }^{g}$ RS2E, Réseau Français sur le Stockage Electrochimique de l'Energie, FR CNRS 3459, F-80039 Amiens Cedex 1, France.

${ }^{h}$ ALISTORE-ERI European Research Institute, FR CNRS 3104, F-80039 Amiens Cedex 1, France.
}

† Corresponding author (L. Croguennec): Laurence.Croguennec@icmcb.cnrs.fr 
The thermogravimetric analysis (TGA) of LVPH-b was performed on a STA 449C (ATG-DSC) Netzsch under air and over a temperature range between 20 and $700^{\circ} \mathrm{C}$, with a continuous heating rate of $5^{\circ} \mathrm{C} / \mathrm{min}$. The results are given in figure $\mathrm{S} 1$ with in blue the weight loss and in red the heat flow.

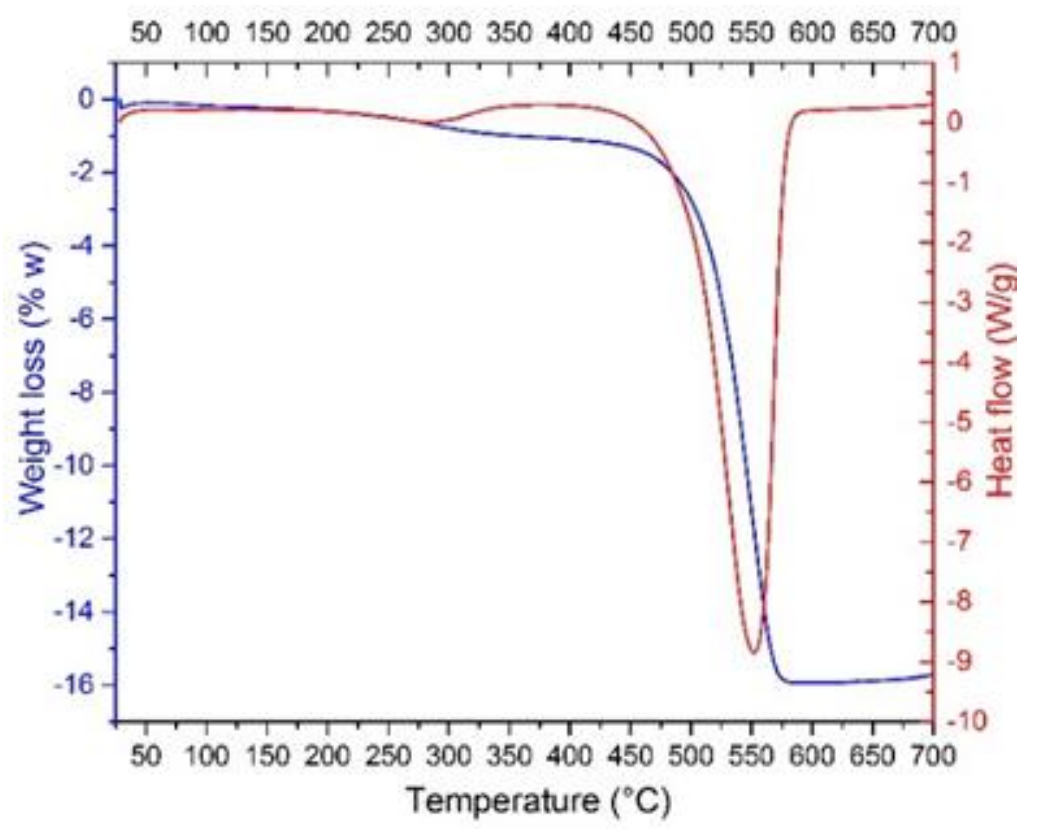

2D EXSY-RFDR ${ }^{7} \mathrm{Li}$ NMR experiments were carried out on samples $b$ and $\mathrm{c}$, using the pulse sequence described in ref (Messinger et al) in the following conditions:

Bruker Avance 300 spectrometer (7T magnet, $116 \mathrm{MHz}$ for 7Li resonance).

Spinning speed: $30 \mathrm{kHz}$ in standard Bruker MAS probe and $2.5 \mathrm{~mm}$ rotors.

(Synchronization thus allows a spectral width of $257 \mathrm{ppm}$ in the indirect dimension.)

$90^{\circ}$ pulse duration: $2 \mathrm{~s}$

Mixing time: $10 \mathrm{~ms}$ (300 rotor periods)

Recycle time: 0.5 microsecond

fp-RFDR pulse train: $64180^{\circ}$ pulses (reintroduces the homonuclear dipolar interaction suppressed by MAS)

States quadrature detection in indirect dimension

For details of the pulse sequence, see ref (Messinger et al). 
Figure S2 shows the 2D map thus obtained for sample c: the spectrum is clearly only seen in the diagonal. No cross peak that would indicate dipolar correlation between the Li species corresponding to the two peaks is observed. One can therefore conclude that these two $\mathrm{Li}$ species are over $5 \mathrm{~A}$ apart, and thus do not belong to the same material.

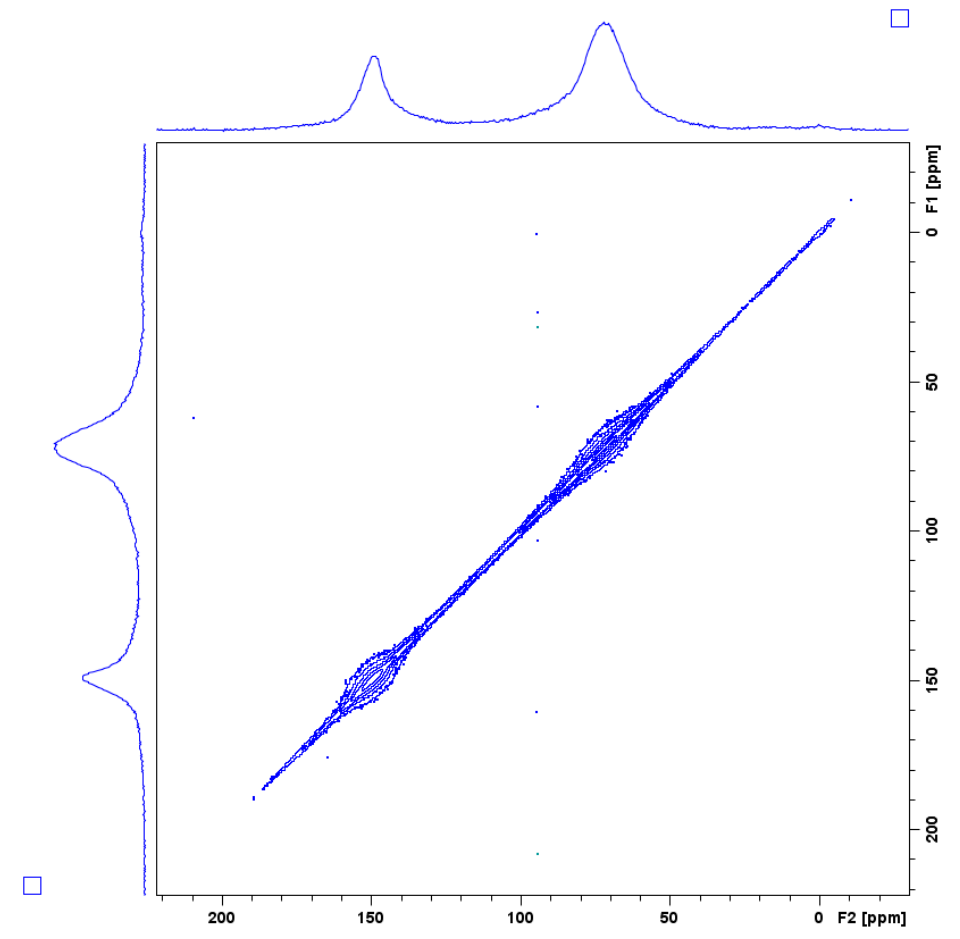

Figure S3 shows the 2D map obtained for sample b. The same conclusion applies although the weaker magnitude of the additional signals in this sample would obviously make it more 
difficult to observe possibly very weak cross-peaks.

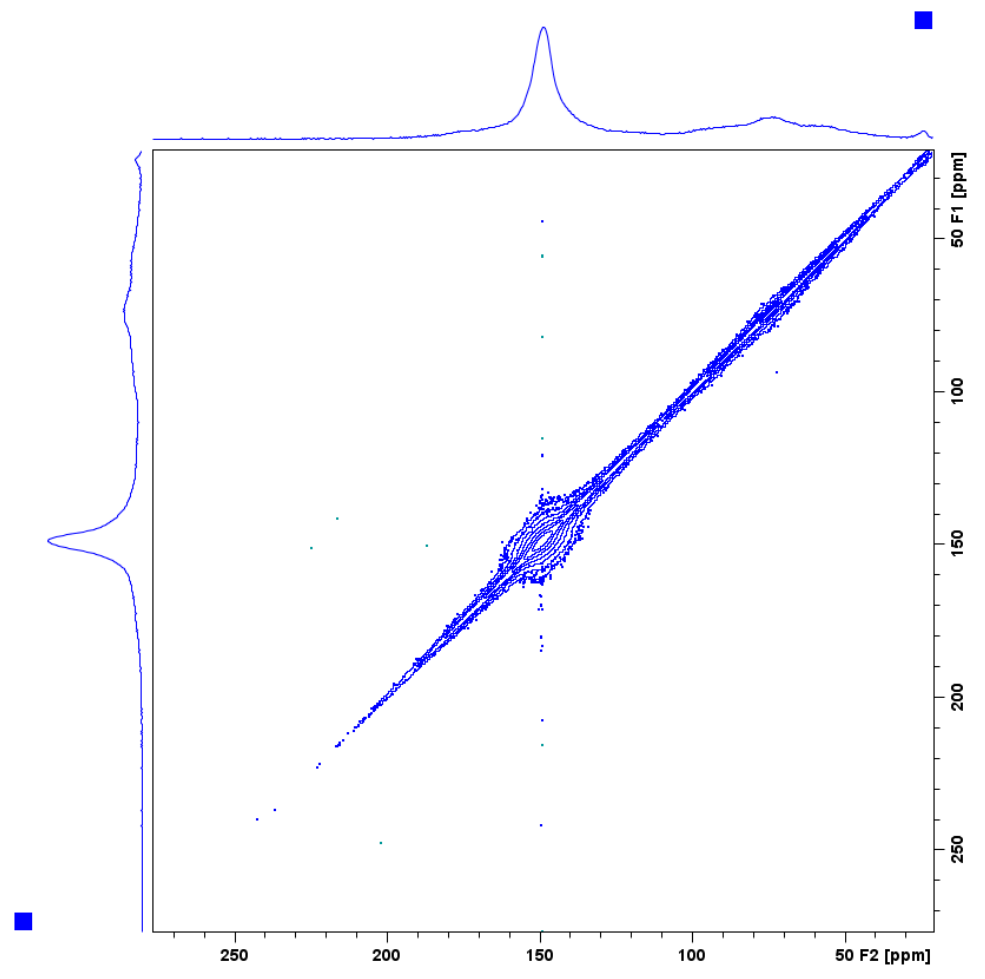

